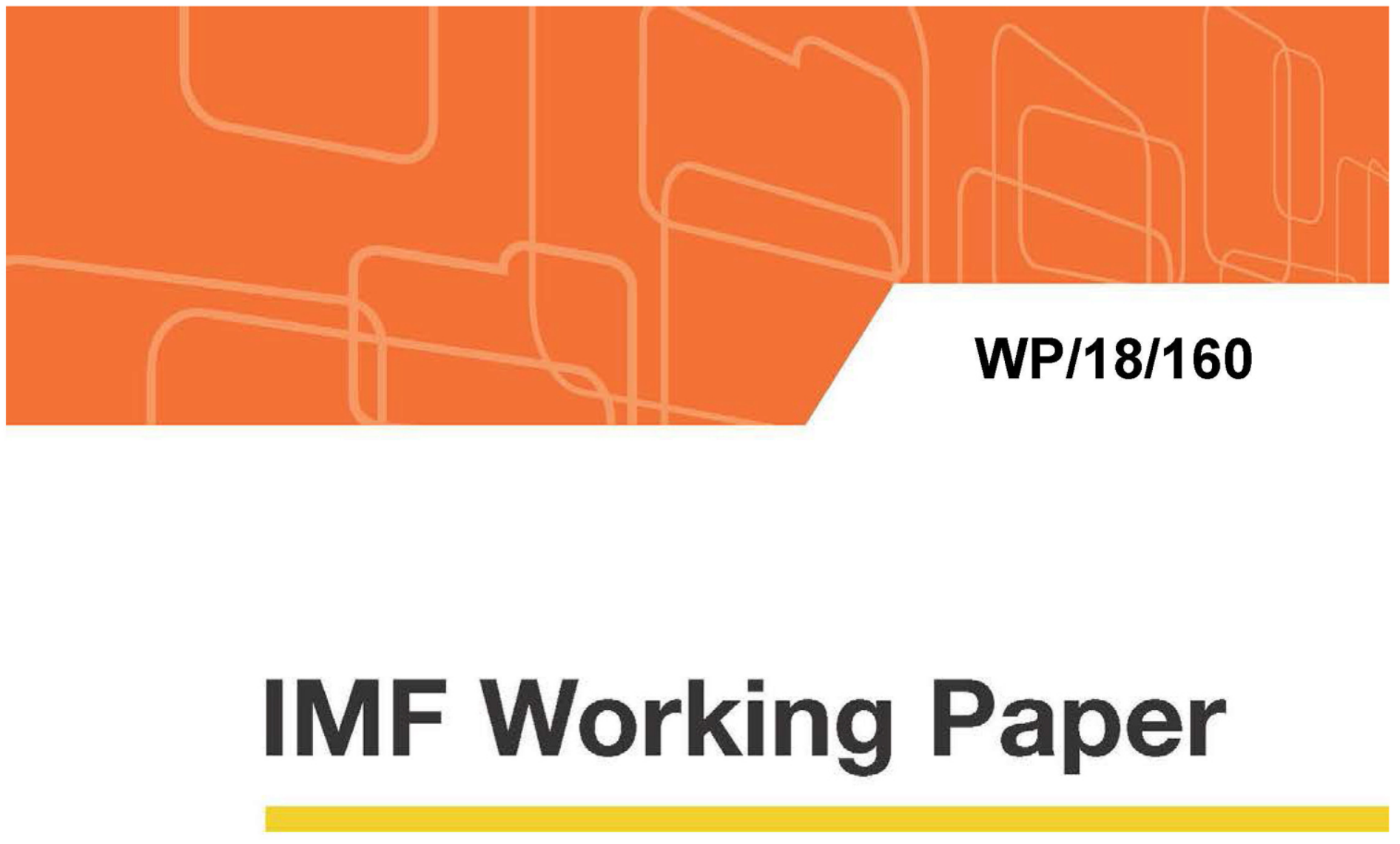

\title{
Housing Price, Credit, and Output Cycles: How Domestic and External Shocks Impact Lithuania's Credit
}

by lacovos loannou

IMF Working Papers describe research in progress by the author(s) and are published to elicit comments and to encourage debate. The views expressed in IMF Working Papers are those of the author(s) and do not necessarily represent the views of the IMF, its Executive Board, or IMF management.

$$
\text { I N T ER N A T I O N A L M O N E T A R Y F U N D }
$$




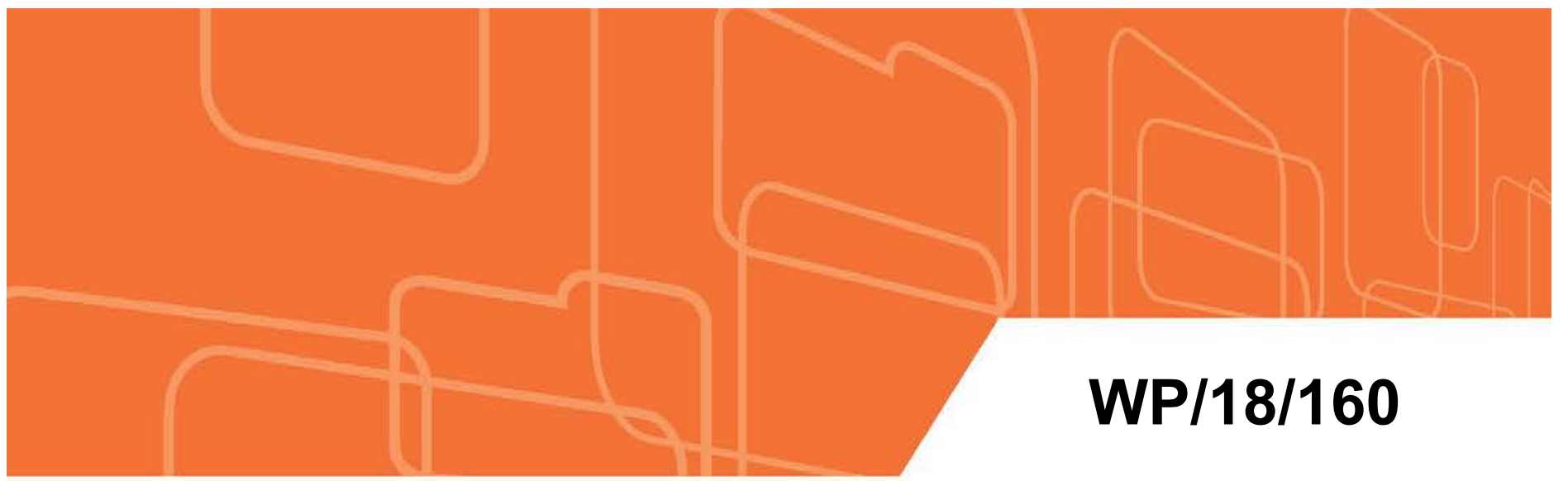

\section{IMF Working Paper}

\section{Housing Price, Credit, and Output Cycles: How Domestic and External Shocks Impact Lithuania's Credit}

by lacovos loannou

IMF Working Papers describe research in progress by the author(s) and are published to elicit comments and to encourage debate. The views expressed in IMF Working Papers are those of the author(s) and do not necessarily represent the views of the IMF, its Executive Board, or IMF management.

$$
\text { I N T ER N A T I O N A L M O N E T A R Y F U N D }
$$




\title{
IMF Working Paper
}

European Department

\section{Housing Price, Credit, and Output Cycles: \\ How Domestic and External Shocks Impact Lithuania's Credit}

Prepared by Iacovos Ioannou ${ }^{1}$

Authorized for distribution by Rachel van Elkan

July 2018

IMF Working Papers describe research in progress by the author(s) and are published to elicit comments and to encourage debate. The views expressed in IMF Working Papers are those of the author(s) and do not necessarily represent the views of the IMF, its Executive Board, or IMF management.

\begin{abstract}
Lithuania's current credit cycle highlights the strong link between housing prices and credit. We explore this relationship in more detail by analyzing the main features of credit, housing price, and output cycles in Baltic and Nordic countries during1995-2017. We find a high degree of synchronization between Lithuania's credit and housing price cycles. Panel regressions show a strong correlation between a credit upturn and housing price upturn. Moreover, panel VAR suggests that shocks in housing prices, credit, and output within and outside Lithuania strongly impact Lithuania's credit.
\end{abstract}

JEL Classification Numbers: E30, E32, E37, E44, F44, F65

Keywords: Credit, house prices, business cycle, macro-financial linkages, contagion Author's E-Mail Address: iioannou@imf.org

\footnotetext{
${ }^{1}$ The author wishes to thank, without implicating, seminar participants at the Bank of Lithuania for helpful comments, Xingwei Hu for programming support, and Nhu Nguyen for excellent research assistance.
} 


\section{Table of Contents}

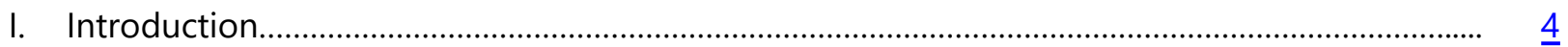

II. The Current Credit Cycle in Comparison with the Pre-Crisis Boom............................................. $\quad \underline{5}$

III. The Main Features and Synchronization of Credit, Housing Price and Output Cycles............... $\quad \underline{9}$

IV. Determinants of Credit Upturns............................................................................................ 12

V. Assessing the Impact of Domestic and External Shocks on Credit...........................................

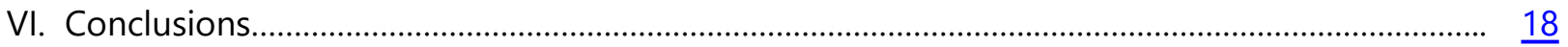

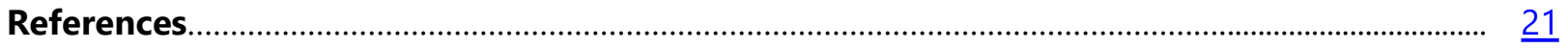

\section{Tables}

1. Credit Cycle Characteristics....................................................................................................

2. Housing Price Cycle Characteristics..................................................................................... 24

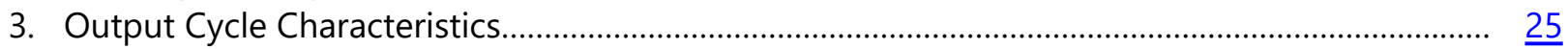

4. Lithuania: Credit, Housing Price, and Output Cycles...............................................................

5. Lithuania: Synchronization of Cycles.................................................................................... $\quad \underline{27}$

6. Determinants of the Presence of a Credit Upturn.................................................................... $\underline{\underline{28}}$

7. Elasticities of Housing Prices, Real Credit, and Real GDP to One percent Shocks...................... $\underline{\underline{29}}$

8. Speed of Adjustment of Housing Prices, Real Credit, and Real GDP to One percent Shocks.... $\underline{30}$

9a. Lithuania's Elasticities and Speed of Adjustment to One percent Shocks in Baltic and Nordic Countries.

9b. Lithuania's Elasticities and Speed of Adjustment to One percent Shocks in Baltic Countries.... $\frac{32}{33}$

9c. Lithuania's Elasticities and Speed of Adjustment to One percent Shocks in Nordic Countries.. $\underline{33}$

10. Lithuania's Elasticities to One percent Aggregate Shocks in Baltic and Nordic Countries.

\section{Figures}

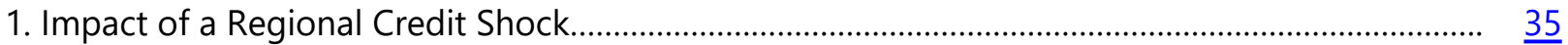

2. Impact of a Regional Housing Price Shock.............................................................................. $\quad \frac{36}{37}$

3. Impact of a Regional Real GDP Shock................................................................................. $\quad \frac{37}{38}$

4. Impact of a Credit Shock in Lithuania....................................................................................... $\quad \underline{38}$

5. Impact of a Housing Price Shock in Lithuania......................................................................... $\quad \underline{39}$

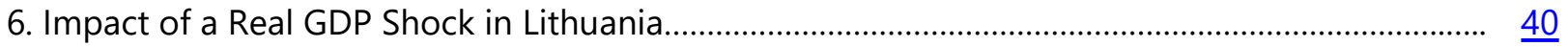

7. Impact of a Country-Specific Credit Shock on Lithuania's Real Credit........................................... $\frac{41}{42}$

8. Impact of a Country-Specific Housing Price Shock on Lithuania's Housing Prices...................... $\underline{42}$

9. Impact of a Country-Specific Real GDP Shock on Lithuania's Real GDP....................................... $\underline{43}$

\section{Annexes}

I. Data Coverage and Sources.................................................................................................

II. Underlying Data on Credit, Housing Prices, and Real GDP.......................................................

III. Impact of Cross-Country Shocks on Lithuania............................................................................. 49 


\section{INTRODUCTION}

1. Credit growth in Lithuania has shown signs of recovery in recent years. After many years of deleveraging following the global financial crisis, private sector credit has begun to grow in mid-2015. Since then, credit has grown annually by 5.2 percent on average. The acceleration of credit has coincided with strong wage growth, rapid increases in housing prices, and rapid expansion of the housing stock. These developments are taking place against the backdrop of a banking system dominated by Nordic banks. Many Nordic countries in recent years have experienced rapid credit growth and sharp housing price increases, although these trends have moderated recently. The main purpose of this paper is to examine how developments in credit, housing markets and the economy within and outside Lithuania impact Lithuania's credit.

2. The paper examines the relationship between credit, housing price, and output cycles by focusing on three main questions:

> How closely are credit, housing price, and output cycles synchronized within Lithuania and across other Baltic and Nordic countries?

$>$ What are the main determinants of a credit recovery?

$>$ How do shocks in credit, housing prices, and output in Lithuania and other Baltic and Nordic countries impact Lithuania's credit?

3. The paper contributes to the existing literature on the interactions between real and financial cycles in two ways: 1) it focuses on credit, housing price, and output cycles in Baltic and Nordic countries, with emphasis on Lithuania, 2) It assesses how shocks in other Baltic and Nordic countries spill over to Lithuania.

4. The rest of the paper is divided in five parts: Part II examines Lithuania's current credit cycle relative to the pre-crisis credit boom. By examining stylized facts about financial crises, it assesses whether the current credit cycle poses risks to financial stability. Part III explores in more detail the relationship between credit, housing price, and output cycles. It describes the main features of these cycles in Lithuania and other Baltic and Nordic countries and their comovements within and across countries. Part IV employs panel regressions to assess the determinants of a credit upturn. It examines whether the housing price and output upturns contribute to the presence of a credit upturn, while controlling for other variables. Part $\mathrm{V}$ assesses potential spillovers from other Baltic and Nordic countries to Lithuania. It examines how credit, housing price, and output shocks in Lithuania and other Baltic and Nordic countries affect, among other things, Lithuania's credit. Part VI concludes by drawing implications for financial stability. 


\section{The Current Credit CyCle in Comparison With the Pre-Crisis Credit Boom}

5. We examine stylized facts (SF) about the current credit cycle relative to the period prior to the global financial crisis. The SFs relate to the pace and level of credit, the funding of the credit cycle, household and corporate balance sheets, interest rates, housing market developments, and credit composition.

6. SF1: Financial crises are associated with high and rapid credit growth. The current growth and stock of credit is well below the pre-crisis years. In the post-crisis years, credit growth peaked at 8.4 percent in August 2016, compared with 64 percent prior to the global financial crisis (April 2006). For households, the corresponding numbers are 9.4 percent (August 2016) and 53.4 percent (April 2006), while for the nonfinancial corporate (NFC) sector 7.8 percent (September 2017) and 128.1 percent (May 2004). Similarly, the outstanding stock of credit at end 2017 was 41.1 percent of GDP, well below the 2009 peak (65.9 percent of GDP).

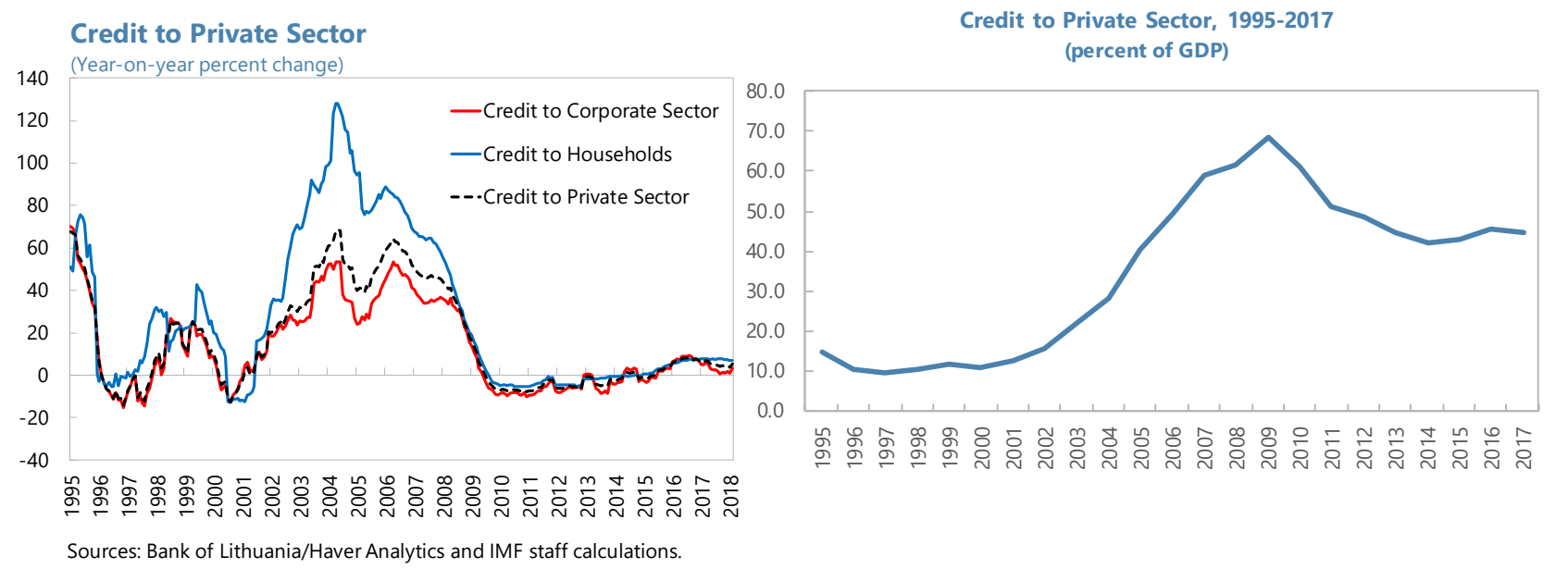

\section{SF2: Financial crises are associated} with a high loan-to-deposit ratio. The funding of the current credit cycle is different from the pre-crisis years. The banking system now relies exclusively on deposits (loan-todeposit ratio below 100) whereas prior to the global financial crisis, the loan-to-deposit ratio had reached 188 percent. Moreover, deposits since 2009Q4 are growing at a faster pace than loans, unlike the pre-crisis period.

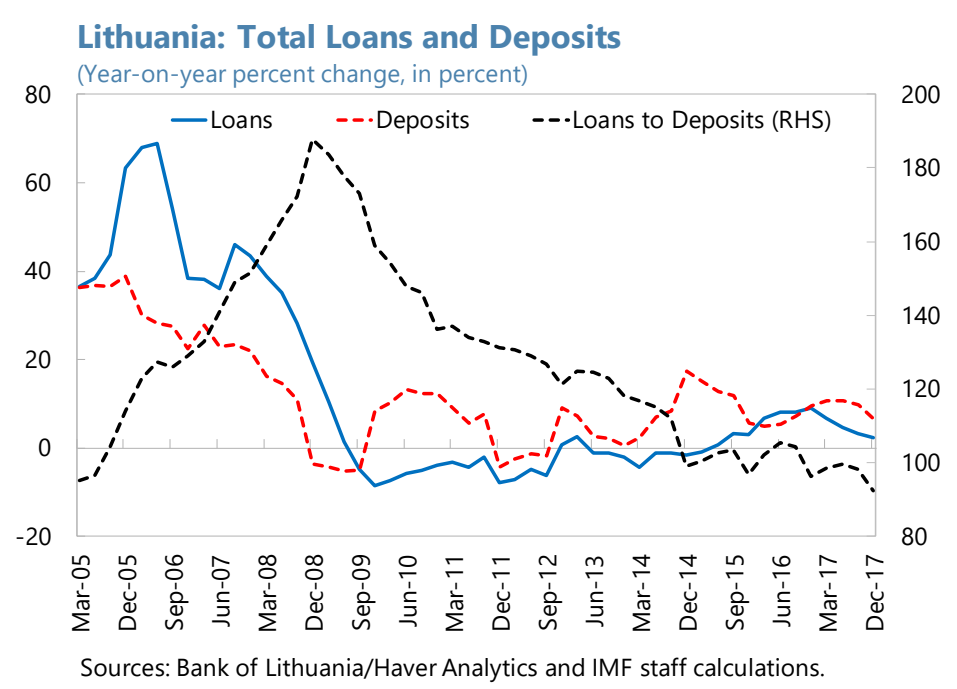


8. SF3: Financial crises are associated with extensive parent funding. Parent funding has been on a steady decline in recent years. Notwithstanding the increased share of bank assets by Nordic banks after the global financial crisis, parent funding as a percent of deposits has declined steadily from a peak of 42.8 percent in $2008 \mathrm{Q} 4$ to 15 percent of total deposits at end-2016.

\section{SF4: Financial crises are}

associated with excessive private sector leveraging. There has been a considerable improvement in household and corporate balance sheets after years of deleveraging. Household indebtedness in the form of loans has declined from a pre-crisis peak of

Assets of Nordic Banks and Funding by Parent Banks

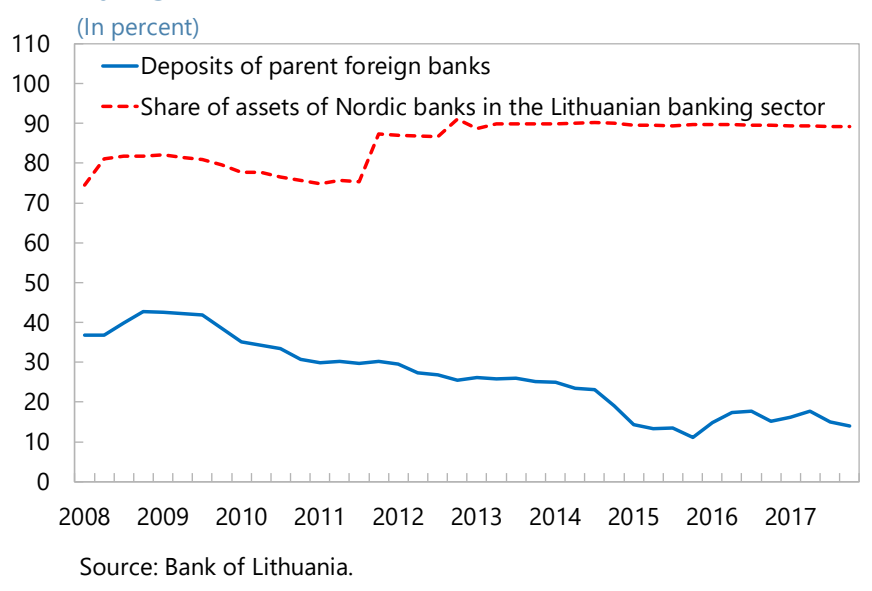

34.0 percent of GDP in March 2009 to 22.3 percent of GDP in 2017Q3. Similarly, corporate indebtedness in the form of loans, has declined sharply, from a peak of 63.6 percent of GDP in March 2009 to 41.9 percent in 2017Q3.

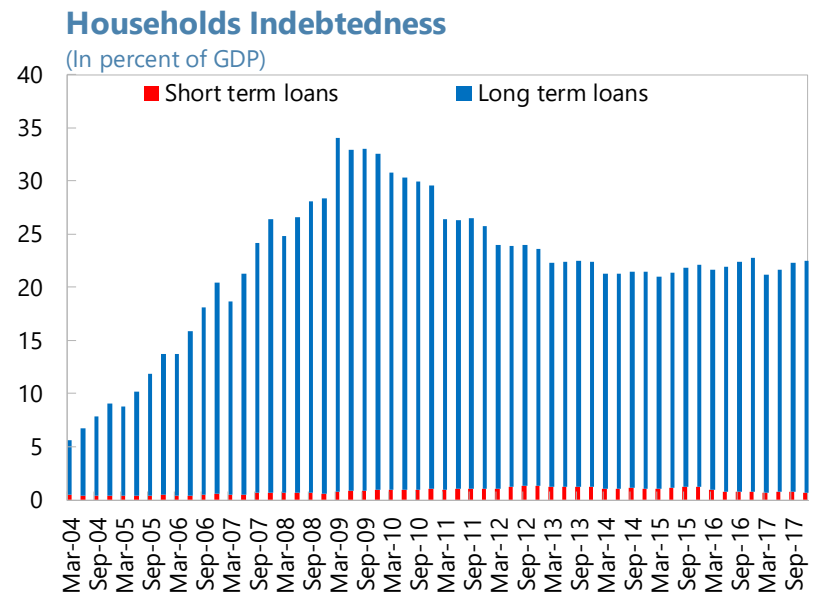

Sources: Bank of Lithuania and IMF staff calculations.

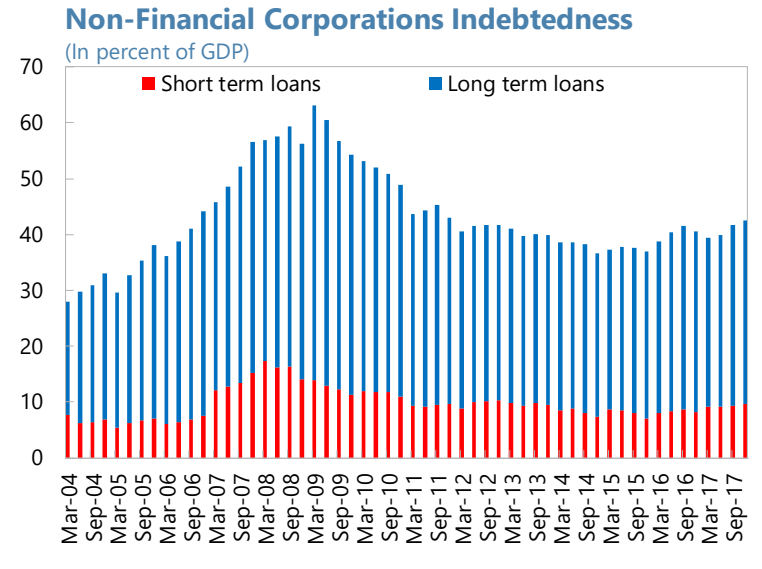

Sources: Bank of Lithuania and IMF staff calculations. 
10. SF5: Financial crises are associated with easy credit conditions. With low interest rates persisting, credit conditions should remain accommodative in the near term. Interest rates for corporate loans and mortgages are near historic lows-2.29 percent for NFCs and 3.66 for households at end-2017-and are likely to support a further expansion of credit. Nevertheless, long term interest rates (in euros) are quite volatile and have climbed again to near post-crisis peaks. The recent steepening of the yield curve may reflect market's expectations about future interest hikes which encourage participants to shift to short-term funding. At the same time, firms

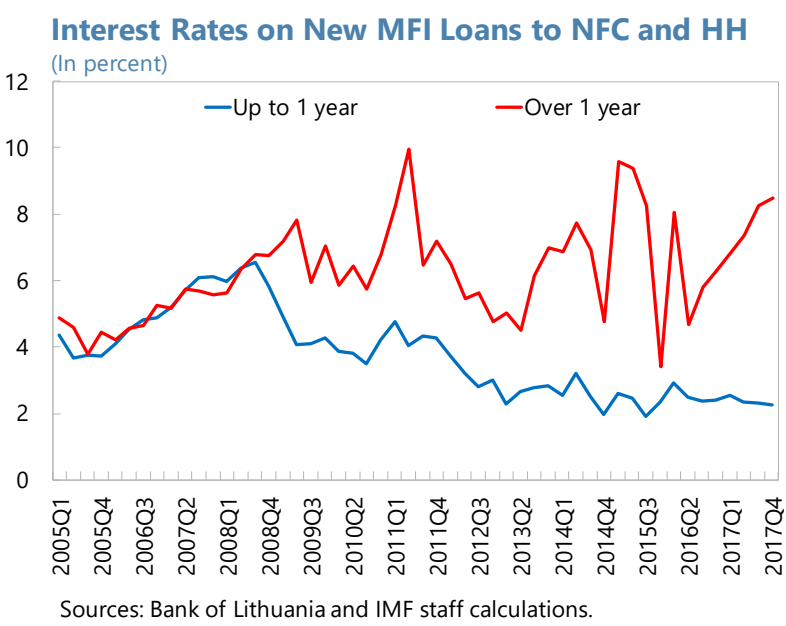

will find it increasingly difficult to finance their expansion plans by relying on internal funds.

11. SF6: Financial crises are associated with a booming housing market. The housing market in Lithuania has recently experienced significant growth. The number of housing transactions has increased steadily since 2010 and is nearing the pre-crisis peak, although recently the pace has declined considerably. Similarly, housing prices have 3000 been rising steadily especially after 2014, but at a markedly slower pace than in the pre-crisis years. Although housing prices remain about 20 percent below the precrisis peak, the impact of rising demand on housing prices may be masked by the rapid expansion of housing supply. Housing

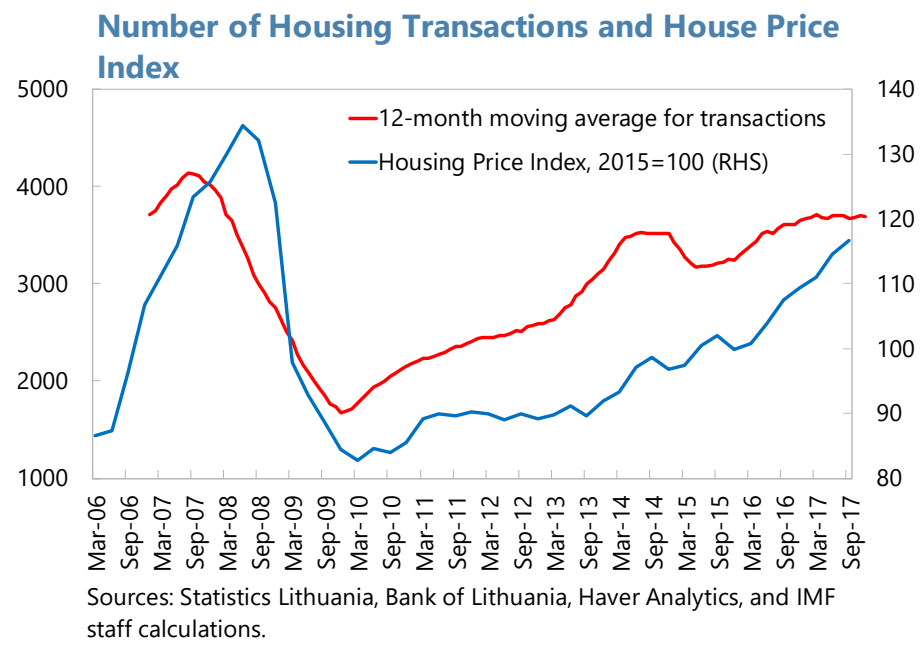
completions and building permits are near, or have exceeded, pre-crisis levels. ${ }^{2}$ Still, the rise in housing prices in large cities after adjusting for inflation remains well below the pre-crisis peak.

\footnotetext{
${ }^{2}$ Activity in commercial real estate (e.g., office space, industrial real estate) may have been fueled by Baltic and Scandinavian investors attracted by a higher return on investment than in Scandinavian countries. Increased reliance on foreign capital may reduce the market's dependence on local funding, but increase contagion risks.
} 

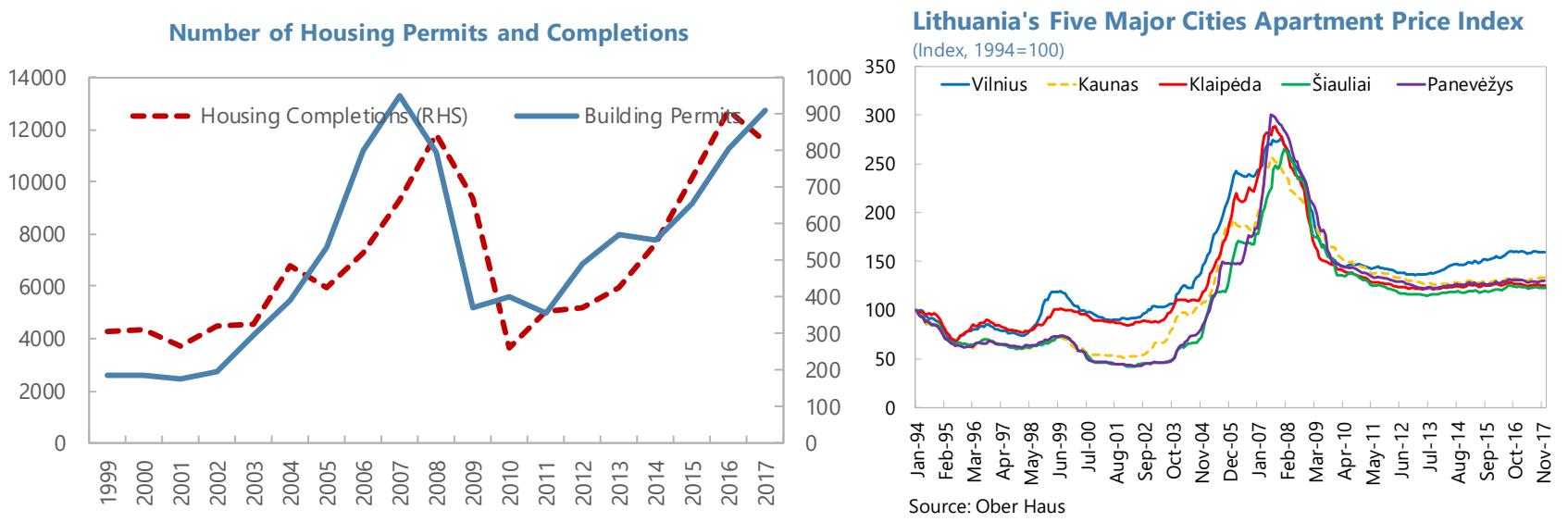

12. SF7: Financial crises are associated with a high share of real estate loans. Housing loans and credit for construction and real estate activities are well above the levels at the peak of the pre-crisis years (April 2006). ${ }^{3}$ The high share of housing and construction and real estate loans generally could be sign of overheating and market speculation. The high concentration of construction and real estate loans in recent years is partially compensated by fewer loans in professional, scientific, and technical activities and other loans.

Structure of the portfolio of MFI loans granted to the private non-financial sector - 2006Q1

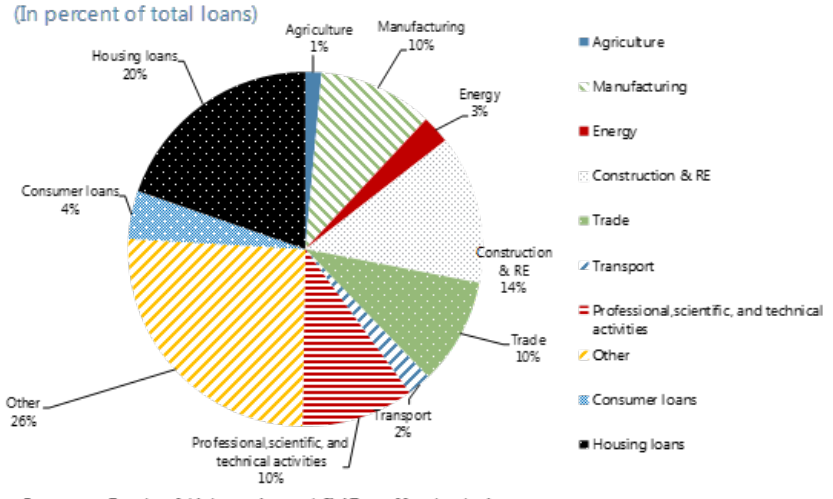

Sources: Bank of Lithuania and IMF staff calculations.
Structure of the portfolio of MFI loans granted to the private non-financial sector - 2017Q3
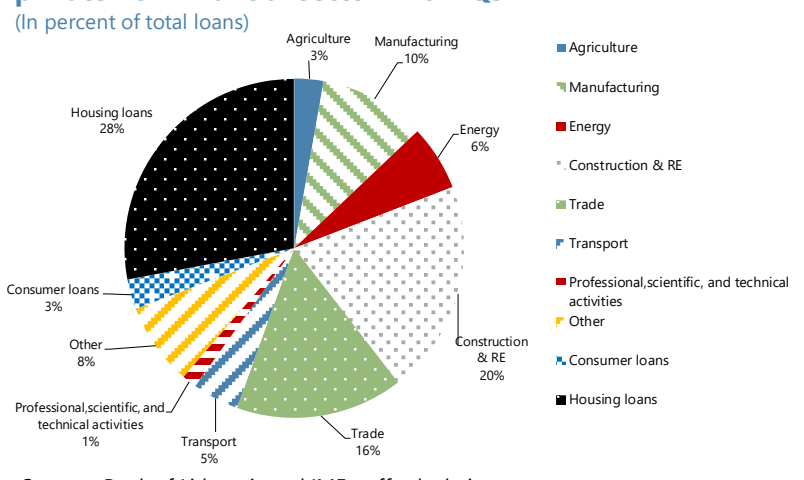

Sources: Bank of Lithuania and IMF staff calculations.

13. Overall, while the rate of credit growth, stock of outstanding credit, loan-to-deposit ratio, and limited parent funding, point to a benign credit cycle, some indicators suggest the need for continued vigilance. Continued low interest rates, rising housing prices, and skewed composition of lending in favor of housing loans, construction and real estate activities point to the need for closely monitoring credit developments.

\footnotetext{
${ }^{3}$ Data are not publicly available for the peak of the cycle (July 2008).
} 


\section{The Main Features and Synchronization of Credit, housing Price, ANd OUtPut CYCLES}

14. This section takes a closer look at the links between credit, housing prices, and the economy. It examines the main features of credit, housing price, and output cycles (frequency, duration, amplitude, slope) in Lithuania and other Baltic and Nordic countries and the degree to which they are synchronized within and across countries.

15. The relationship among credit, asset prices, and output cycles has been extensively studied. In a world without financial frictions, macroeconomic developments and financial conditions interact through wealth and substitution effects (Cochrane, 2005). Intuitively, purchases of financial assets represent an intertemporal substitution of consumption. Booming asset prices raise wealth and therefore boost spending capacity. In the real world (with frictions), the link between the real economy and financial markets (e.g., Bernanke and Gertler, 1989; Kiyotake and Moore, 1997; and Adrian and Shin, 2010) originates primarily from firms' need to finance investment. Because of asymmetric information, lenders require borrowers to demonstrate their ability to repay using collateralized assets. An increase in asset prices improves firms' balance sheet and net worth, resulting in higher borrowing capacity and investment. The ensuing increase in output further increases asset prices, which leads to a feedback loop of rising asset prices, improved balance sheets, eased credit conditions and increasing economic activity. Because a small change in financial markets can produce a large change in economic conditions this theory has been dubbed financial accelerator. It suggests that credit cycles tend to amplify real economic cycles owing to the procyclicality of bank lending.

16. The paper uses quarterly data for seven Baltic and Nordic countries over the period 1995-2017Q3. The sample period reflects data availability constraints in Baltic countries during the early post-independence years. To measure the credit cycle, we use data on loans by monetary financial institutions to household and NFC sectors. For the output cycle, we use real GDP (chained volume series). Finally, to examine the housing price cycle we use data on house price index by the OECD. All data are in constant prices (deflated using the CPI), and seasonally adjusted. Annex I provides more details on data coverage and sources.

17. The paper uses the "classical" definition of the output cycle to create a chronology of cycles. ${ }^{4}$ The classical methodology focuses on changes in the levels of economic activity to identify cyclical turning points. Its main advantage over estimating cycles using detrended series is that turning points are robust to the addition of new data.

\footnotetext{
4 The classical approach dates back to Burns and Mitchel (1946) and is used by the National Bureau of Economic Research (NBER) and the Center for Economic Policy Research (CERP) to determine turning points in US and euro area output cycles.
} 
18. The paper uses the algorithm introduced by Harding and Pagan (2002) to identify turning points in the log-level of a quarterly series. The algorithm searches for maximums and minimums over a given period. Then, it imposes censoring rules to pairs of adjacent, locally absolute maximums and minimums to ensure a minimal duration of cycles and phases. The algorithm requires a minimum duration of a complete cycle of five quarters and of each phase of the cycle of at least two quarters. ${ }^{5}$ Specifically, a peak in a quarterly series yt occurs at time $t$ if:

$$
\left\{\left[\left(y_{t}-y_{t-2}\right)>0,\left(y_{t}-y_{t-1}\right)>0\right] \text { and }\left[\left(y_{t+2}-y_{t}\right)<0,\left(y_{t+1}-y_{t}\right)<0\right]\right\}
$$

Similarly, a cyclical trough occurs at time $t$ if:

$$
\left\{\left[\left(y_{t}-y_{t-2}\right)<0,\left(y_{t}-y_{t-1}\right)<0\right] \text { and }\left[\left(y_{t+2}-y_{t}\right)>0,\left(y_{t+1}-y_{t}\right)>0\right]\right\}
$$

A complete cycle consists of two phases: the downturn (contraction) phase which is the period from peak to trough, and the upturn (expansion) phase which is the period from trough to the next peak.

19. We first analyze the main features of identified cycles: duration, amplitude, and slope. The duration of an upturn, $D u$, is defined as the number of quarters, $k$, it takes for a variable to reach its peak after a trough. The duration of a downturn, $D d$, is defined as the number of quarters, $k$, it takes for a variable to reach a trough after its peak. The amplitude of an upturn, $A u$, is the change in $y_{t}$ from a trough, $y_{m}$, to the next peak, $y_{p}$, i.e., $A d=y_{p}-y_{m}$. The amplitude of a downturn, $A d$, is the change in $y_{t}$ from its peak, $y_{p}$, to the next trough, $y_{m}$, i.e., $A d=y_{m}-y_{p}$. Finally, the slope of a cycle is a measure of the speed of a given cyclical phase. For an upturn, it is measured as the ratio of the amplitude, $A u$, to the duration, $D u$, of the upturn. For a downturn, it is measured as the ratio of the amplitude, $A d$, to the duration, $D d$, of the downturn.

20. Lithuania has undergone two complete credit cycles since 1995 and is currently in the upturn phase of a third cycle. Credit cycles in Lithuania and other Baltic and Nordic countries are not symmetric: downturns are much shallower and short lived (Table 1). The average duration of a credit upturn in Lithuania has been almost double that of a downturn (19 quarters against 10 quarters). In other countries, credit upturns last even longer. The average duration of credit upturns in Baltic and Nordic countries is almost three times that of downturns. In addition, the average amplitude of credit upturns is much bigger than of downturns reflecting the long duration of upturns. Normalizing the amplitude by duration, reveals that the speed (slope) of upturns and downturns in Lithuania is the lowest among the Baltics. Relative to the Nordics, Lithuania has the highest upturn speed, but less than average downturn speed.

21. Lithuania's housing price cycle is more volatile (more upturns and more downturns) than that of most Baltic and Nordic countries (Table 2). Housing prices in Lithuania are in an upturn

\footnotetext{
${ }^{5}$ On a few occasions, the algorithm was complimented by judgment when it yielded conflicting information (e.g., adjacent maximum and minimums).
} 
for a little more than half of the time, one of the lowest among Baltic and Nordic countries. The average duration of an upturn is 7.7 quarters, the second lowest among peers. Nevertheless, Lithuania's housing prices increase more rapidly than peers during an upturn (slope) and decline more slowly during a downturn.

22. Lithuania's output (economy) has been in an upturn/downturn for a longer/shorter period than other Baltic and Nordic countries (Table 3). Lithuania's output has been in an upturn 87 percent of the time and the average duration was 26 quarters, which is rather typical across peers. Lithuania's downturns, on the other hand, have been shorter than those in other Baltic and Nordic countries. Overall, both the speed of upturns and downturns in Lithuania has been faster than the average in Baltic and Nordic countries.

23. A comparison of Lithuania's three cycles reveals that housing price cycles are the most frequent (Table 4). Of the three cycles, output upturns last the longest and housing price upturns the shortest. On the down phase, credit downturns last the longest and output downturns the shortest. Credit changes at the fastest pace (slope) both during upturns and downturns. Housing prices adjust the least during downturns, an indication of downward rigidity.

24. To assess the extent of synchronization among the credit, housing price, and output cycles, we use the concordance index developed by Harding and Pagan (2002). The concordance index is a measure of the fraction of time two series are in the same phase of their respective cycles. The index, $\mathrm{Cl}_{x y}$ for variables $\mathrm{x}$ and $\mathrm{y}$ is defined as:

$$
\text { CIxy }=\frac{1}{T} \sum_{t=1}^{T}\left[C_{{ }^{x}}^{x} * C_{t}^{y}+\left(1-C_{t}^{x}\right) *\left(1-C_{t}^{y}\right)\right]
$$

where $C_{t}^{x}$ and $C_{t}^{y}$ are binary variables whose values change depending on the phase of the cycle the underlying series are in. More specifically:

$C_{t^{x}}=\{0$, if $x$ is in downturn phase at time $t ; 1$, if $x$ is in upturn phase at time $t\}$

$C_{t} y=\{0$, if $y$ is in downturn phase at time $t ; 1$, if $y$ is in upturn phase at time $t\}$

$T=$ the number of time periods in the sample.

25. The two series are perfectly procyclical (countercyclical) if the concordance index is equal to unity (zero). We calculate Lithuania's concordance index for the following pairs: credit-housing prices, credit-output, and housing prices-output. In addition, we examine the concordance of Lithuania's credit, housing price, and output cycles with those of other Baltic and Nordic countries.

26. We first examine comovements among Lithuania's three cycles. The results show that Lithuania's credit cycle is highly synchronized with Lithuania's housing price cycle, but less so 
with the output cycle (Table 5). The strongest comovement among Lithuania's three cycles is between the credit and housing price cycles (concordance of 0.77 ). The weakest synchronization is between Lithuania's credit and output cycles (concordance index of 0.60). Lithuania's output cycle has a higher synchronization with the housing price cycle than the credit cycle.

27. Looking at the comovement of a cycle in Lithuania and the same cycle in another country, reveals that Lithuania's credit cycle is more closely synchronized with Estonia's and Denmark's credit cycles. Lithuania's housing price cycle is more synchronized with Denmark's and Estonia's housing price cycles, and Lithuania's output cycle with Estonia's and Norway's output cycles. In general, Lithuania's output cycle is the most synchronized with other countries' output cycles (average concordance of 0.84), followed by Lithuania's credit cycle (average concordance of 0.67). Not surprisingly, Lithuania's housing price cycle is the least synchronized (average concordance of 0.60 ), suggesting that housing prices in Lithuania are mainly affected by local conditions.

28. Among all the cycles, the range of synchronization varies from a high of 0.91 in the case of Lithuania's and Estonia's output cycles to a low of 0.45 in the case of Lithuania's credit cycle and Denmark's output cycle. The three highest concordances involve Lithuania's output cycle, which suggests that Lithuania's output cycle is the most synchronized among all the cycles. Lithuania's credit cycle is most highly synchronized with Estonia's credit cycle, Lithuania's housing price cycle with Lithuania's credit cycle, and Lithuania's output cycle with Estonia's output cycle.

29. In conclusion, the analysis in this section suggests that Lithuania's credit cycle is most closely linked to housing price developments in Lithuania. Moreover, credit and housing price developments in other countries have, on average, a considerable impact on Lithuania's credit. In contrast, economic developments in the region have a somewhat lesser effect on Lithuania's credit. These results should be interpreted with caution because they are based on cycle comovements and ignore other factors which may influence credit.

\section{Determinants of Credit Upturns}

30. To get a better sense of the factors that influence credit upturns (given Lithuania's current cyclical context), we examine the influence of housing price and output upturns, while controlling for other variables. The paper uses panel regressions with fixed effects to model the presence of a credit upturn (dependent variable) against a set of explanatory variables related to credit demand and supply. ${ }^{6}$ The fixed effect model (country dummies) assumes that certain country-specific characteristics are not captured by explanatory variables and that omitted variables are uncorrelated with explanatory variables. Fixed effects models correct for the

\footnotetext{
${ }^{6}$ Because the number of credit recoveries identified in the previous section is not sufficiently large, the analysis focuses on the determinants of the presence of a credit upturn. We have not extended the analysis to the determinants of housing price and output upturns because the primary focus is on the credit cycle.
} 
omitted variable bias by assuming that omitted variables have the same impact on a country over time.

31. The regressors include the presence of an economic upturn, the existence of an upturn in housing prices, the existence of a credit downturn during the global financial crisis (dummy variable) to assess whether credit is more likely to bounce back after a sharp downturn, and various proxies of credit demand (interest rate, private sector indebtedness) and supply (deposit growth, inflation, profitability). Since the dependent variable and some of the independent variables are binary variables, we use logit estimation to determine the significance of parameter coefficients.

32. More specifically, the econometric specification is:

$$
C R_{p r}=\beta X_{i t}+\gamma_{\mathrm{i}}+\varepsilon_{i t}
$$

where:

$C R_{p r}=$ Presence of credit upturn, a binary variable that takes the value of one when credit is in an upturn phase of the cycle, zero otherwise.

$X_{i t}=$ Set of variables in country i during period t correlated with the dependent variable, notably:

$>$ Presence of a housing price upturn, a binary variable taking the value of one when housing prices are in an upturn phase of the cycle, zero otherwise

$>$ Presence of an economic output upturn, a binary variable taking the value of 1 when output (real GDP) is in an upturn phase of the cycle, zero otherwise

$>$ Presence of a credit downturn during the global financial crisis (dummy variable), a binary variable that takes the value of one during 2007-08, zero otherwise

$>$ Interest rate, measured by the 3-month money market rate

$>$ Private sector indebtedness, defined as the sum of household and NCF sector indebtedness, as a percent of GDP

$>$ Consumer inflation, measured by the harmonized index of consumer prices

$>$ Deposit growth, measured by household and NFC deposits

$>$ Banks' return on assets

$\gamma_{i}=$ Country fixed effects (dummy variables that take the value of 1 for country $\mathrm{i}$, zero otherwise)

33. The results of the regression analysis are shown in Table 6. The results confirm the strong role that a housing price upturn has on the presence of a credit upturn. Under all specifications, 
the coefficient of the housing price upturn is positive and statistically significant. In contrast, the output cycle does not have a significant impact on the presence of a credit upturn when one controls for the presence of other variables. To some extent, this result is consistent with the earlier analysis which found the concordance of Lithuania's credit cycle with the output cycle in Lithuania and other Baltic and Nordic countries to be the weakest. In a sense, other variables may substitute for the role played by the economy. The analysis finds strong support for credit supply factors such as bank profitability, deposit availability, and inflation. Bank profitability is positively correlated with the presence of a credit upturn and this result is robust across specifications. ${ }^{7}$ Deposit growth also seems to positively contribute to the presence of a credit upturn. Inflation negatively influences the presence of credit upturn, as expected. The analysis also finds support for credit demand factors such as the interest rate and private sector indebtedness. While the interest rate coefficient is significant in all specifications, it enters with a negative sign in some and with a positive sign in others, highlighting a possible identification problem. ${ }^{8}$ Nevertheless, in the presence of all variables (equation 8), a higher interest rate reduces the likelihood of a credit upturn, implying that the parameter captures credit demand. Private sector indebtedness is negatively correlated with the presence of credit upturns, suggesting that high levels of debt dampen credit demand by reducing loan eligibility.

34. In conclusion, regression analysis provides further support for the strong link between credit and housing prices. The analysis does not find evidence that an economic upturn contributes to the presence of a credit upturn when controlling for credit demand and supply variables.

\section{Assessing the IMPACt Of Domestic AND External Shocks On CRedit}

35. This section looks beyond the variables that contribute to a credit upturn and focuses on how credit, housing price, and output shocks impact one another. We employ panel vector autoregression (VAR) analysis to assess how credit, housing price, and output shocks in Lithuania and in other Baltic and Nordic countries are transmitted. The analysis focuses mainly on the impact and transmission speed of these shocks on Lithuania's credit, but it also covers briefly the impact of these shocks on Lithuania's housing prices and output.

36. The VAR uses a system of interrelated variables (endogenous variables) for which economic theory does not provide insights on the direction of causality and/or the appropriate dynamic specification. The general model specification is the following:

\footnotetext{
7 The regression analysis also used capital adequacy instead of return on assets. While the results generally had the correct sign and were statistically significant, they were not as robust.

${ }^{8}$ The relationship between credit and the interest rate could represent either credit demand (if the coefficient has a negative sign) or credit supply (if the coefficient has a positive sign), depending on the volatility of these curves.
} 


$$
G(L) Y_{t}=c+\varepsilon t
$$

where: $G(L)=5 \times 5$ polynomial in the lag operator ${ }^{9}$

$$
\begin{aligned}
& Y_{t}=5 \times 1 \text { vector of endogenous variables } \\
& c=5 \times 1 \text { vector of constants } \\
& \varepsilon t=5 \times 1 \text { vector of innovations. }{ }^{10}
\end{aligned}
$$

The vector of endogenous variables used in the VAR includes:

$$
Y_{t}=\left[\begin{array}{c}
\text { GDP } \\
\text { HPI } \\
\text { CR } \\
\mathrm{R} \\
\mathrm{CAR}
\end{array}\right]
$$

where:

$$
\begin{aligned}
& \mathrm{GDP}=\text { log difference in real GDP } \\
& \mathrm{HPI}=\text { log difference in the real housing price index } \\
& \mathrm{CR}=\text { log difference in real credit } \\
& \mathrm{R}=\text { change in 3-month money market rate } \\
& C A R=\text { change in capital adequacy. }
\end{aligned}
$$

The VAR is estimated in differences to ensure stationarity in the data. Annex II provides graphs of the underlying data on credit, housing prices, and real GDP for all countries in the sample.

37. Diagnostic tests validate the VAR specification. Results of unit root tests suggest that all differenced series are I(0). Lag selection tests point to the inclusion of one lag in the VAR specification. Also, the VAR satisfies the stability condition with the no roots lying outside the unit circle.

\footnotetext{
${ }^{9}$ Since only lagged values of the endogenous variables appear on the right-hand side of the equations, simultaneity is not an issue.

${ }^{10}$ Innovations may be contemporaneously correlated (e.g., $\varepsilon_{1 \mathrm{t}}$ and $\varepsilon_{2 \mathrm{t}}$ may be correlated), but uncorrelated with their own lagged values (e.g., $\varepsilon_{1 \mathrm{t}}$ and $\varepsilon_{1 \mathrm{t}-1}$ ) and all right-hand-side variables. This assumption is tested by ensuring that residuals are a white noise.
} 
38. Based on the VAR specification, we then use impulse response functions to analyze the dynamic impact of random disturbances on the system variables. Impulse response functions trace the effect of a one-time temporary shock to one variable (more precisely to the innovations associated with the variable) on current and future values of all the endogenous variables. ${ }^{11}$

39. We first calculate impulse response functions for "regional" shocks, i.e., shocks which affect all Baltic and Nordic countries simultaneously (e.g., a random disturbance on housing prices common to all sample countries). The region's response to these shocks provides a helpful yardstick by which to draw comparisons. We then examine Lithuania's response to its own country-specific shocks. In both cases, the main emphasis is on how Lithuania's credit responds to shocks,

40. Figures 1-6 and Tables 7 and 8 summarize the main results. In general, Lithuania's elasticities (sensitivity to shocks) are higher than the region's (Table 7), suggesting that Lithuania is more prone to volatility. Lithuania's credit is highly vulnerable to all shocks. The biggest vulnerability is to credit shocks, followed by output, and housing price shocks. Credit's responsiveness to these shocks far exceeds that of the region, underscoring Lithuania's vulnerability to economic and financial shocks. In both the region and Lithuania, credit shocks do not have a large impact on real GDP. Instead, the reverse is true: real GDP shocks have a strong impact on real credit.

41. The speed of adjustment to shocks is considerably lower in Lithuania than in the Baltic and Nordic region (Table 8). Credit's response to shocks is slower in Lithuania than in the region, especially its response to real GDP shocks. Credit shocks also have the most protracted impact on Lithuania's real GDP and housing prices (by far the smallest speed of adjustment among all shocks). The most rapidly transmitted shock in Lithuania is a housing price shock which translates to rapid gains in real GDP.

42. We now examine how shocks in individual Baltic and Nordic countries affect Lithuania's credit, housing prices, and real GDP. The results are summarized in Table 9. First, we analyze the interconnectedness of credit, housing prices, and real GDP in Lithuania and other Baltic and Nordic countries, namely the extent to which a shock in another country affects that variable in Lithuania. We begin by examining how credit shocks in other Baltic and Nordic countries affect Lithuania's credit, and then repeat this analysis for housing price shocks and real GDP shocks.

43. Credit developments in Lithuania and other Baltic and Nordic countries are the most strongly interconnected, i.e., the elasticity of Lithuania's credit to own (credit) shocks in other countries is the highest (Table 9a-9c and Figure 7). On average, a one percent credit shock in other Baltic and Nordic countries leads to a 1.9 percent increase in Lithuania's credit, with 68 percent of the adjustment taking place within four quarters. There is, however, large variability

\footnotetext{
${ }^{11}$ A shock to a given variable not only directly affects that variable, but is transmitted through the lag structure of the VAR to all other endogenous variables.
} 
among countries. The biggest positive impact on Lithuania's credit comes from credit shocks in Denmark, followed by Finland, and Latvia. Credit shocks in Estonia, Norway and Sweden have a negative impact on Lithuania's credit. The negative impact may result from different channels. First, parent banks may funnel resources to domestic markets by reducing exposure to Lithuania. Second, credit growth in those countries may prompt preemptive regulatory response in Lithuania to address concerns about overheating. Third, confidence effects may lead households and NFCs to reduce demand for credit and/or rely on internal resources to fund investment.

44. Housing prices are the least interconnected (Table 9a-9c and Figure 8). On average, a one percent shock in housing prices in Baltic and Nordic countries leads to a 0.7 percent increase in housing prices in Lithuania, with 80 percent of the adjustment taking place within four quarters. There is, however, considerable variability depending on the shocks' country of origin. The biggest positive impact on Lithuania's housing prices comes from shocks in Denmark, followed by Estonia, and Finland. In contrast, housing price shocks in Norway and Sweden have a negative impact. The negative elasticity suggests that investors may consider real estate purchases in Lithuania a substitute for investments in Norway and Sweden. The largest decline in Lithuania's housing prices is from housing price shocks in Sweden.

45. Lithuania's economy is moderately interconnected to other Baltic and Nordic countries (Figure 9). On average, a one percent real GDP shock in Baltic and Nordic countries leads to a 1.1 percent increase in Lithuania's real GDP, with 87 percent of the adjustment taking place within four quarters. The speed of adjustment is the highest among all shocks. Real GDP shocks in other Baltic and Nordic countries all have a positive impact on Lithuania's real GDP. The biggest impact is from a real GDP shock in Finland, followed by Sweden. Shocks in other countries do not exert a significant impact on Lithuania's real GDP.

46. Cross-variable shocks ${ }^{12}$ have a sizable impact on Lithuania (Table 9a-9c and Annex III). Of all the shocks, the most powerful is the effect of a real GDP shock in Baltic and Nordic countries on Lithuania's credit. On average, a one percent real GDP shock in Baltic and Nordic countries leads to a 2.4 percent increase in credit in Lithuania. Housing price shocks in Baltic and Nordic countries also have a sizable impact on Lithuania's credit, with a one percent shock in Baltic and Nordic countries leading to a 2.0 percent increase of Lithuania's credit. Among the other crossvariable shocks, the only significant one is the effect of a real GDP shock in Baltic and Nordic countries on Lithuania's housing prices. The least pronounced cross-variable shock is the effect of a credit shock in Baltic and Nordic countries on Lithuania's real GDP. This result may be indicative of reverse causality: real economic developments affect credit rather than the other way around.

47. Shocks in other Baltic and Nordic countries are generally transmitted quickly except for credit shocks (Table 9a-9c). Credit shocks in other Baltic and Nordic countries take considerably

\footnotetext{
12 Defined as shocks in one variable in Baltic and Nordic countries which affect another variable in Lithuania.
} 
longer to be transmitted to Lithuania: Lithuania's credit, housing price, and real GDP response to credit shocks is among the weakest. On the other hand, the transmission of housing price and real GDP shocks on real GDP is the fastest among all shocks. In both cases, 87 percent of the adjustment is completed within four quarters. Housing price and real GDP shocks also have a rapid transmission to Lithuania's housing prices.

48. Of all the Baltic and Nordic countries, Lithuania is most vulnerable to shocks from Finland (Table 10). Aggregate shocks from Finland (average of housing price, credit, and real GDP shocks) have the largest impact on Lithuania, with housing price, credit, and real GDP elasticities well above those for other countries. Shocks from Denmark and Sweden also have a strong impact on Lithuania's credit. Shocks from Norway and Latvia seem to have the least impact.

\section{Conclusions}

49. The current credit cycle, while benign, highlights the strong link between credit and housing prices. This link is confirmed by the strong comovement between Lithuania's credit and housing price cycles. Further investigation using panel regressions confirms the strong relationship between the presence of a credit upturn and the presence of a housing price upturn.

50. The VAR analysis shows that all shocks have a strong impact on Lithuania's credit, regardless of whether they originate in Lithuania or other Baltic and Nordic countries. It also confirms the strong impact of housing prices on Lithuania's credit. In general, Lithuania's credit is more sensitive (higher elasticities) to shocks than the Baltic and Nordic region. Moreover, shocks have a more protracted impact on credit than in the Baltic and Nordic region, especially credit shocks. Shocks in other Baltic and Nordic countries also have a significant impact on Lithuania's credit.

51. Beyond credit, there are a few additional conclusions that are noteworthy. First, housing prices are more responsive to local conditions because the impact of shocks in other Baltic and Nordic countries on Lithuania's housing prices is rather limited. Second, domestic credit shocks do not significantly impact Lithuania's economy. Finally, economic shocks in other Baltic and Nordic countries have a significant impact on Lithuania's housing prices and economy.

52. The analysis above has important implications for Lithuania's financial stability. In general, Lithuania's high elasticity of credit to domestic shocks relative to the Baltic and Nordic region, suggests that Lithuania may be more prone to financial volatility (sensitivity to shocks).

Furthermore, the lower speed of adjustment in Lithuania's credit relative to the Baltic and Nordic region suggests that credit volatility may last longer in Lithuania than the Baltic and Nordic region. The authorities should therefore proactively respond to shocks by preventing credit, housing, and economic imbalances from building up to minimize their impact on credit. ${ }^{13}$

\footnotetext{
${ }^{13}$ The high elasticity of credit to shocks may be indicative of "herd behavior" and panic response to shocks, which regulators should consider when designing an appropriate policy response.
} 
Moreover, the authorities should take measures to facilitate credit's adjustment to shocks. In general, large differences in credit's speed of adjustment relative to the Baltic and Nordic region may be due to rigidities. Regulators may want to review and, where necessary, streamline existing regulations to facilitate credit's adjustment to domestic shocks.

53. The authorities should also closely monitor housing price, credit, and economic developments in other Baltic and Nordic countries. Shocks in these countries have large and often unpredictable impact on Lithuania's credit. To minimize risks, the authorities should seek to further deepen cooperation in the context of the Nordic-Baltic Stability Group to facilitate early response to shocks.

54. There are also important implications for financial stability related to specific shocks.

$>$ Housing prices both in Lithuania and other Baltic and Nordic countries have a strong impact on Lithuania's credit and could pose significant risks to financial stability. Therefore, it is important to monitor closely housing prices (and more broadly housing market developments), not only in Lithuania, but in other Baltic and Nordic countries. Regulators may consider developing close working relationships with real estate market participants to assess underlying trends.

$>$ The authorities should take into account strong macro-financial links to preserve financial stability. Real GDP shocks in Lithuania and other Baltic and Nordic countries have a strong impact on Lithuania's credit. This implies that financial institutions may respond to economic developments when extending credit. Credit procyclicality poses risks to financial stability and calls for reinforced supervision and regulation. It also underscores the importance of sound macroeconomic and structural policies to safeguard steady and sustainable growth and preserve financial stability. In contrast, the low elasticity of real GDP to credit shocks suggests that policies to ease credit to boost economic growth are unlikely to be effective.

$>$ Credit developments have the potential to be destabilizing. The high elasticity of credit to credit shocks in Lithuania and other countries, combined with a relatively slow transmission, poses significant risks for protracted credit downturns.

55. The analysis above has implications for economic stability more broadly. Lithuania's economy is vulnerable to domestic housing price shocks. The strong response of Lithuania's real GDP to domestic housing price shocks may be indicative of a strong wealth effect which could further destabilize the economy (consumers spend less when prices go down and vice versa). Moreover, there are strong links between Lithuania's economy and those of other Baltic and Nordic economies. GDP shocks in other countries, on average, have a considerable impact on Lithuania's economy. It is therefore important to monitor closely economic developments in other countries. 
56. Given the above risks, Lithuania should proactively use macroprudential policy to manage risks. Doing so may not always be easy because it is difficult to identify shocks as they happen (in our analysis, the identification of shocks happens after the fact), making the adoption of timely macroprudential action difficult. This is especially important because policymakers should consider not only the benefits of macroprudential policy for financial stability, but also potential costs in the form of distortions, costs to borrowers from reduced availability of financial services, costs to financial institutions from adherence to new regulations, and potential costs to the economy (output loss). Moreover, while the Bank of Lithuania possesses the powers and instruments to tackle risks, in a continuously evolving financial sector, the authorities should periodically review macroprudential instruments to ensure that that these remain effective in tackling systemic risks. Effective macroprudential policy should also be supported by strong supervision and enforcement, and complimented by appropriate macroeconomic and structural policies.

57. Finally, a few caveats. The conclusions of the analysis are based on a sample of data covering the period 1995-2017Q3. Following the global financial crisis, Lithuania has implemented strong measures to reduce its vulnerability to shocks. It is therefore possible that Lithuania now operates in a more benign environment than implied by the analysis. Moreover, differences in financial development in Baltic and Nordic countries may have not been fully captured in the empirical analysis undermining the accuracy of the results. Despite these caveats, the main conclusions and policy recommendations remain valid. 


\section{References}

Adrian, Tobias and Hyun Song Shin, 2010, "Liquidity and Leverage," Journal of Financial Intermediation, 19 (3), 418-437.

Bernanke, B., and M. Gertler, 1989, "Agency Costs, Net Worth, and Business Fluctuations," American Economic Review, 79 (1), 14-31.

Bernanke, B., M. Gertler, and S. Gilchrist, 1999, "The Financial Accelerator in a Quantitative Business Cycle Framework," in Handbook of Macroeconomics Volume 1, ed. by J. B. Taylor and M. Woodford (New York: Elsevier).

Burns, Arthur F., and Wesley C. Mitchell, 1946, Measuring Business Cycles (New York: NBER).

Carrol, Christopher D., Misuzu Otsuka, and Jirka Slacalek, 2006, "How Large Is the Housing Wealth Effect? A New Approach," JHU Economics Working Paper Archive 535.

Cecchetti, Stephen G, 2006, "Measuring the Macroeconomic Risks Posed by Asset Price Booms," in J.Y. Campbell (ed.) Asset Prices and Monetary Policy, U of Chicago Press.

Cerutti, Eugenio, Jihad Dagher, and Giovanni Dell'Ariccia, 2015a, "Housing Finance and Realestate Booms: A Cross-Country Perspective," IMF Staff Discussion Note 15/12 (Washington: International Monetary Fund).

Che, Natasha Xingyuan," and Yoko Shinagawa, 2014, "Financial Soundness Indicators and the Characteristics of Financial Cycles," IMF Working Paper, 14.

Claessens, Stijn, M. Ayhan Kose, and Marco E. Terrones, 2011, "Financial Cycles: What? How? When?", IMF Working Paper, 76.

__ 2011, "How do business and financial cycles interact?", IMF Working Paper, 88.

Cochrane, John H., 2005, "Financial Markets and the Real Economy," NBER Working Paper, 11193.

Constantinescu, Mihnea and Povilas Lastauskas, 2017, "The Knotty Interplay Between Credit and Housing," Bank of Lithuania Working Paper, 45.

Croux, C., M. Forni, and L. Reichlin, 2001, "A Measure of Comovement for Economic Variables, Theory and Empirics," The Review of Economics and Statistics, 83(2), 232-241.

Dell'Ariccia, Giovanni, Deniz Igan, Luc Laeven, and Hui Tong, with Bas Bakker and Jerome Vandenbussche, 2012, "Policies for Macrofinancial Stability: How to Deal with Credit Booms," IMF Staff Discussion Note 12/06 (Washington: International Monetary Fund).

Feldstein, M., 2007, "Housing, Credit Markets and the Business Cycle," NBER Working Paper, 13471. 
Harding, Don and Adrian Pagan, 2002, "Dissecting the Cycle: A Methodological Investigation," Journal of Monetary Economics Vol. 49, pp. 365-81.

Haroon Mumtaz and Paolo Surico, 2009, "The Transmission of International Shocks: A FactorAugmented VAR Approach," Journal of Money, Credit and Banking, 41, Supplement 1, 71-100.

Helbling, Thomas, and Raju Huidrom, M. Ayhan Kose, and Christopher Otrok, 2010, "Do Credit Shocks Matter? A Global Perspective," IMF Working Paper, 261.

Igan, Deniz, Alain Kabundi, Francisco Nadal De Simone, Marcelo Pinheiro, and Natalia Tamarisa, 2009, "Three Cycles: Housing, Credit, and Real Activity," IMF Working Paper, 231.

International Monetary Fund, 2014, "Finland: 2014 Article IV Consultation-Staff Report" (Washington: International Monetary Fund).

_ 2014, "Sweden: 2014 Article IV Consultation—Staff Report" (Washington: International Monetary Fund).

_ 2014, "Norway: 2014 Article IV Consultation—Staff Report" (Washington: International Monetary Fund).

_ , 2014, "Baltic Cluster Report_-Selected Issues paper" (Washington: International Monetary Fund).

Kiyotaki, N. and J. Moore, 1997, "Credit Cycles," Journal of Political Economy, 105(2), 211-248.

Mendoza, Enrique, and Marco E. Terrones, 2008, "An Anatomy of Credit Booms: Evidence from Macro Aggregates and Micro Data," NBER Working Paper, 14049. 


\begin{tabular}{|c|c|c|c|c|c|c|c|c|c|c|}
\hline \multicolumn{11}{|c|}{ Table 1. Credit Cycle Characteristics } \\
\hline & Lithuania & Latvia & Estonia & Sweden & Norway & Denmark & Finland & Average & Median & $\begin{array}{l}\text { Standard } \\
\text { Deviation }\end{array}$ \\
\hline Number of upturns & 3.0 & 1.0 & 4.0 & 6.0 & 6.0 & 3.0 & 3.0 & 3.7 & 3.0 & 1.7 \\
\hline Number of downturns & 3.0 & 2.0 & 4.0 & 6.0 & 5.0 & 2.0 & 2.0 & 3.4 & 3.0 & 1.5 \\
\hline Number of quarters in upturn & 55.0 & 45.0 & 56.0 & 65.0 & 67.0 & 72.0 & 85.0 & 63.6 & 65.0 & 12.1 \\
\hline Number of quarters in downturn & 31.0 & 44.0 & 26.0 & 15.0 & 11.0 & 15.0 & 2.0 & 20.6 & 15.0 & 13.0 \\
\hline Time in upturn (percent) & 60.4 & 49.5 & 62.2 & 71.4 & 75.3 & 79.1 & 93.4 & 70.2 & 71.4 & 13.3 \\
\hline Time in downturn (percent) & 34.1 & 48.4 & 28.9 & 16.5 & 12.4 & 16.5 & 2.2 & 22.7 & 16.5 & 14.3 \\
\hline Duration of upturn (average) & 19.0 & 45.0 & 14.3 & 10.8 & 11.2 & 24.0 & 28.3 & 21.8 & 19.0 & 11.2 \\
\hline Duration of downturn (average) & 10.0 & 21.5 & 7.0 & 2.8 & 2.2 & 7.5 & 1.0 & 7.4 & 7.0 & 6.5 \\
\hline Amplitude of upturn (average), percent & 358.1 & 3750.0 & 188.1 & 25.7 & 36.3 & 48.2 & 95.6 & 643.1 & 95.6 & 1273.0 \\
\hline Amplitude of downturn (average), percent & -28.0 & -55.5 & -17.1 & -6.5 & -9.6 & -4.0 & -0.7 & -17.3 & -9.6 & 17.8 \\
\hline Slope of upturn 1/ & 12.8 & 83.3 & 18.1 & 2.7 & 2.9 & 1.0 & 2.2 & 17.6 & 2.9 & 27.5 \\
\hline Slope of downturn $1 /$ & -3.3 & -8.4 & -3.6 & -4.4 & -6.5 & -0.9 & -0.7 & -4.0 & -3.6 & 2.6 \\
\hline
\end{tabular}




\begin{tabular}{|c|c|c|c|c|c|c|c|c|c|c|}
\hline \multicolumn{11}{|c|}{ Table 2. Housing Price Cycle Characteristics } \\
\hline & Lithuania & Latvia & Estonia & Sweden & Norway & Denmark & Finland & Average & Median & $\begin{array}{l}\text { Standard } \\
\text { Deviation }\end{array}$ \\
\hline Number of upturns & 6.0 & 7.0 & 4.0 & 3.0 & 5.0 & 2.0 & 3.0 & 4.3 & 4.0 & 1.7 \\
\hline Number of downturns & 5.0 & 7.0 & 5.0 & 3.0 & 5.0 & 1.0 & 4.0 & 4.3 & 5.0 & 1.7 \\
\hline Number of quarters in upturn & 46.0 & 45.0 & 53.0 & 76.0 & 71.0 & 69.0 & 50.0 & 58.6 & 53.0 & 12.0 \\
\hline Number of quarters in downturn & 32.0 & 33.0 & 27.0 & 10.0 & 9.0 & 20.0 & 32.0 & 23.3 & 27.0 & 9.6 \\
\hline Time in upturn (percent) & 51.7 & 49.5 & 60.2 & 83.5 & 79.8 & 75.8 & 56.2 & 65.2 & 60.2 & 13.1 \\
\hline Time in downturn (percent) & 36.0 & 36.3 & 30.7 & 11.0 & 10.1 & 22.0 & 36.0 & 26.0 & 30.7 & 10.8 \\
\hline Duration of upturn (average) & 7.7 & 3.6 & 12.4 & 25.3 & 14.2 & 34.5 & 16.0 & 16.2 & 14.2 & 9.8 \\
\hline Duration of downturn (average) & 5.5 & 4.7 & 6.8 & 3.3 & 2.3 & 20.0 & 8.5 & 7.3 & 5.5 & 5.5 \\
\hline Amplitude of upturn (average), percent & 35.4 & 23.6 & 24.3 & 66.2 & 32.2 & 83.0 & 30.1 & 42.1 & 32.2 & 21.4 \\
\hline Amplitude of downturn (average), percent & -11.9 & -12.8 & -22.1 & -4.5 & -4.8 & -28.2 & -5.6 & -12.9 & -11.9 & 8.5 \\
\hline Slope of upturn 1/ & 5.8 & 6.3 & 1.0 & 2.4 & 2.2 & 2.0 & 1.9 & 3.1 & 2.2 & 1.9 \\
\hline Slope of downturn 1/ & -1.2 & -2.4 & -2.8 & -1.3 & -1.9 & -1.4 & -1.2 & -1.7 & -1.4 & 0.6 \\
\hline
\end{tabular}




\begin{tabular}{|c|c|c|c|c|c|c|c|c|c|c|}
\hline & & Table & Output C & e Characte & tics & & & & & \\
\hline & Lithuania & Latvia & Estonia & Sweden & Norway & Denmark & Finland & Average & Median & $\begin{array}{l}\text { Standard } \\
\text { Deviation }\end{array}$ \\
\hline Number of upturns & 3.0 & 3.0 & 3.0 & 3.0 & 2.0 & 4.0 & 3.0 & 3.0 & 3.0 & 0.5 \\
\hline Number of downturns & 2.0 & 3.0 & 3.0 & 2.0 & 1.0 & 3.0 & 2.0 & 2.3 & 2.0 & 0.7 \\
\hline Number of quarters in upturn & 79.0 & 74.0 & 77.0 & 79.0 & 79.0 & 68.0 & 71.0 & 75.3 & 77.0 & 4.1 \\
\hline Number of quarters in downturn & 8.0 & 12.0 & 9.0 & 8.0 & 10.0 & 17.0 & 16.0 & 11.4 & 10.0 & 3.5 \\
\hline Time in upturn (percent) & 86.8 & 81.3 & 84.6 & 86.8 & 86.8 & 74.7 & 78.0 & 82.7 & 84.6 & 4.5 \\
\hline Time in downturn (percent) & 8.8 & 13.2 & 9.9 & 8.8 & 11.0 & 18.7 & 17.6 & 12.6 & 11.0 & 3.8 \\
\hline Duration of upturn (average) & 26.3 & 24.7 & 26.0 & 26.3 & 39.5 & 17.0 & 23.7 & 26.2 & 26.0 & 6.2 \\
\hline Duration of downturn (average) & 4.0 & 4.5 & 4.5 & 4.0 & 10.0 & 5.7 & 8.0 & 5.8 & 4.5 & 2.1 \\
\hline Amplitude of upturn (average), percent & 48.2 & 48.6 & 47.9 & 25.4 & 30.7 & 10.9 & 26.1 & 34.0 & 30.7 & 13.6 \\
\hline Amplitude of downturn (average), percent & -9.8 & -11.9 & -11.7 & -4.3 & -4.2 & -2.8 & -6.8 & -7.4 & -6.8 & 3.5 \\
\hline Slope of upturn 1/ & 1.8 & 2.1 & 1.9 & 1.0 & 0.7 & 1.0 & 0.8 & 1.3 & 1.0 & 0.5 \\
\hline Slope of downturn $1 /$ & -2.2 & -2.0 & -2.2 & -1.1 & -0.4 & -0.6 & -1.2 & -1.4 & -1.2 & 0.7 \\
\hline
\end{tabular}




\begin{tabular}{|lrrr|}
\hline \multicolumn{4}{|c|}{ Table 4. Lithuania: Credit, Housing Price, and Output Cycles } \\
\hline & & & \\
& Credit & Housing & Output \\
& Cycle & Price Cycle & Cycle \\
\hline & & & \\
Number of upturns & 3.0 & 6.0 & 3.0 \\
Number of downturns & 3.0 & 5.0 & 2.0 \\
Number of quarters in upturn & 55.0 & 46.0 & 79.0 \\
Number of quarters in downturn & 31.0 & 32.0 & 8.0 \\
Time in upturn (percent) & 60.4 & 51.7 & 86.8 \\
Time in downturn (percent) & 34.1 & 36.0 & 8.8 \\
Duration of upturn (average) & 19.0 & 7.7 & 26.3 \\
Duration of downturn (average) & 10.0 & 5.5 & 4.0 \\
Amplitude of upturn (average), percent & 358.1 & 35.4 & 48.2 \\
Amplitude of downturn (average), percent & -28.0 & -11.9 & -9.8 \\
Slope of upturn 1/ & 12.8 & 5.8 & 1.8 \\
Slope of downturn 1/ & -3.3 & -1.2 & -2.2 \\
\hline Sources: IMF staff estimates. & & & \\
1/ Average growth during upturn/downturn. & & & \\
\hline
\end{tabular}




\begin{tabular}{|c|c|c|c|}
\hline \multicolumn{4}{|c|}{ Table 5. Lithuania: Synchronization of Cycles } \\
\hline & $\begin{array}{c}\text { Credit } \\
\text { cycle }\end{array}$ & $\begin{array}{r}\text { Housing } \\
\text { price cycle }\end{array}$ & $\begin{array}{r}\text { Output } \\
\text { cycle }\end{array}$ \\
\hline \multicolumn{4}{|l|}{ Lithuania's concordance index with: } \\
\hline \multicolumn{4}{|l|}{ Credit cycle } \\
\hline $\begin{array}{l}\text { Baltic and Nordic countries 1/ } \\
\text { Lithuania }\end{array}$ & $\begin{array}{r}0.67 \\
\ldots\end{array}$ & $\begin{array}{l}0.64 \\
0.77\end{array}$ & $\begin{array}{l}0.72 \\
0.60\end{array}$ \\
\hline Latvia & 0.68 & 0.60 & 0.53 \\
\hline Estonia & 0.85 & 0.75 & 0.74 \\
\hline Sweden & 0.57 & 0.60 & 0.73 \\
\hline Norway & 0.49 & 0.53 & 0.76 \\
\hline Denmark & 0.77 & 0.67 & 0.77 \\
\hline Finland & 0.67 & 0.57 & 0.89 \\
\hline \multicolumn{4}{|l|}{ Housing price cycle } \\
\hline Baltic and Nordic countries 1/ & 0.64 & 0.60 & 0.69 \\
\hline Lithuania & 0.77 & $\ldots$ & 0.64 \\
\hline Latvia & 0.65 & 0.59 & 0.63 \\
\hline Estonia & 0.65 & 0.62 & 0.65 \\
\hline Sweden & 0.66 & 0.56 & 0.79 \\
\hline Norway & 0.48 & 0.54 & 0.79 \\
\hline Denmark & 0.70 & 0.67 & 0.79 \\
\hline Finland & 0.58 & 0.59 & 0.54 \\
\hline \multicolumn{4}{|l|}{ Output cycle } \\
\hline Baltic and Nordic countries 1/ & 0.59 & 0.61 & 0.84 \\
\hline Lithuania & 0.60 & 0.64 & \\
\hline Latvia & 0.62 & 0.54 & 0.86 \\
\hline Estonia & 0.58 & 0.57 & 0.91 \\
\hline Sweden & 0.65 & 0.66 & 0.85 \\
\hline Norway & 0.66 & 0.67 & 0.90 \\
\hline Denmark & 0.45 & 0.57 & 0.76 \\
\hline Finland & 0.60 & 0.62 & 0.78 \\
\hline
\end{tabular}




\begin{tabular}{|c|c|c|c|c|c|c|c|c|}
\hline & $(1)$ & (2) & (3) & (4) & $(5)$ & (6) & $(7)$ & $(8)$ \\
\hline Presence of upturn in housing price cycle & $\begin{array}{c}1.218 \text { * } \\
(-0.205)\end{array}$ & $\begin{array}{l}1.261 \text { * } \\
(0.216)\end{array}$ & $\begin{array}{l}1.374 \text { * } \\
(0.222)\end{array}$ & $\begin{array}{l}1.194 \text { * } \\
(0.228)\end{array}$ & $\begin{array}{l}1.435 \text { * } \\
(0.243)\end{array}$ & $\begin{array}{l}1.385 \text { * } \\
(0.256)\end{array}$ & $\begin{array}{l}1.359 \text { * } \\
(0.267)\end{array}$ & $\begin{array}{l}1.301 * \\
(0.268)\end{array}$ \\
\hline Presence of upturn in output cycle & & $\begin{array}{r}-0.180 \\
(0.72)\end{array}$ & $\begin{array}{r}0.149 \\
(0.304)\end{array}$ & $\begin{array}{r}0.041 \\
(0.322)\end{array}$ & $\begin{array}{r}0.087 \\
(0.326)\end{array}$ & $\begin{array}{l}-0.209 \\
(0.365)\end{array}$ & $\begin{array}{c}-0.142 \\
(0.380)\end{array}$ & $\begin{array}{l}-0.224 \\
(0.382)\end{array}$ \\
\hline Presence of global financial crisis (dummy variable) & & & $\begin{array}{l}1.233^{*} \\
(0.423)\end{array}$ & $\begin{array}{c}0.767 \\
(0.436)\end{array}$ & $\begin{array}{r}0.465 \\
(0.450)\end{array}$ & $\begin{array}{r}0.821 \\
(0.493)\end{array}$ & $\begin{array}{l}2.290 \text { * } \\
(0.598)\end{array}$ & $\begin{array}{l}2.769 * \\
(0.635)\end{array}$ \\
\hline Return on assets & & & & $\begin{array}{l}0.424 \text { * } \\
(0.112)\end{array}$ & $\begin{array}{l}0.397 \text { * } \\
(0.114)\end{array}$ & $\begin{array}{l}0.422 \text { * } \\
(0.116)\end{array}$ & $\begin{array}{l}0.426 \text { * } \\
(0.119)\end{array}$ & $\begin{array}{l}0.327 \text { * } \\
(0.121)\end{array}$ \\
\hline Interest rate & & & & & $\begin{array}{l}0.200 \text { * } \\
(0.055)\end{array}$ & $\begin{array}{l}0.119 \text { * } \\
(0.058)\end{array}$ & $\begin{array}{r}-0.369 \text { * } \\
(0.103)\end{array}$ & $\begin{array}{r}-0.450 * \\
(0.110)\end{array}$ \\
\hline Deposit growth rate & & & & & & $\begin{array}{l}0.181 \text { * } \\
(0.031)\end{array}$ & $\begin{array}{l}0.156 \text { * } \\
(0.031)\end{array}$ & $\begin{array}{l}0.168 \text { * } \\
(0.032)\end{array}$ \\
\hline Inflation rate & & & & & & & $\begin{array}{c}-0.075 \text { * } \\
(0.014)\end{array}$ & $\begin{array}{r}-0.051 \text { * } \\
(0.017)\end{array}$ \\
\hline Private sector indebtedness (percent of GDP) & & & & & & & & $\begin{array}{c}-0.020 \text { * } \\
(0.008)\end{array}$ \\
\hline Number of observations & 637 & 637 & 637 & 637 & 637 & 637 & 637 & 637 \\
\hline
\end{tabular}


Table 7. Elasticities of Housing Prices, Real Credit, and Real GDP to One Percent Shocks

\begin{tabular}{|lrrrrrrrrr}
\hline & \multicolumn{2}{c}{ Housing Prices } & & \multicolumn{2}{c}{ Real Credit } & & \multicolumn{2}{c|}{ Real GDP } \\
\cline { 2 - 3 } & Region & Lithuania & & Region & Lithuania & & Region & Lithuania \\
\hline Housing price shock & 2.01 & 10.05 & & 0.89 & 3.00 & & 0.42 & 1.65 \\
Real credit shock & 0.10 & 3.00 & & 1.43 & 13.50 & & 0.06 & 0.75 \\
Real GDP shock & 0.78 & 0.30 & & 1.60 & 6.20 & & 1.22 & 1.91 \\
\hline
\end{tabular}


Table 8. Speed of Adjustment of Housing Prices, Real Credit, and Real GDP to One Percent Shocks (percent of total adjustment within four quarters)

\begin{tabular}{|c|c|c|c|c|c|c|}
\hline & \multicolumn{2}{|c|}{ Housing Prices } & \multicolumn{2}{|c|}{ Real Credit } & \multicolumn{2}{|c|}{ Real GDP } \\
\hline & Region & Lithuania & Region & Lithuania & Region & Lithuania \\
\hline Housing price shock & 92 & 90 & 79 & 73 & 84 & 94 \\
\hline Real credit shock & 75 & 47 & 97 & 70 & 75 & 43 \\
\hline Real GDP shock & 81 & 57 & 89 & 61 & 94 & 89 \\
\hline
\end{tabular}


Table 9a. Lithuania's Elasticities and Speed of Adjustment to One Percent Shocks in Baltic and Nordic Countries

\begin{tabular}{|c|c|c|c|c|c|c|}
\hline & \multicolumn{3}{|c|}{ Average Baltic-Nordic shocks } & \multicolumn{3}{|c|}{ STDEV Baltic-Nordic shocks } \\
\hline & $\begin{array}{r}\text { Housing } \\
\text { Prices }\end{array}$ & Credit & Real GDP & $\begin{array}{r}\text { Housing } \\
\text { Prices }\end{array}$ & Credit & Real GDP \\
\hline \multicolumn{7}{|l|}{ Elasticities } \\
\hline \multicolumn{7}{|c|}{ Lithuania's Response } \\
\hline Housing Prices & 0.7 & 0.4 & 1.3 & 1.2 & 1.2 & 2.5 \\
\hline Real Credit & 2.0 & 1.9 & 2.4 & 1.7 & 3.3 & 3.1 \\
\hline Real GDP & 0.2 & 0.1 & 1.1 & 0.5 & 0.3 & 1.0 \\
\hline \multicolumn{7}{|c|}{$\begin{array}{l}\text { Lithuania's speed of adjustment } \\
\text { (percent of total adjustment within four quarters) }\end{array}$} \\
\hline Housing Prices & 80.1 & 66.8 & 79.7 & 15.9 & 18.4 & 12.4 \\
\hline Real Credit & 74.2 & 68.2 & 66.7 & 6.0 & 3.5 & 2.8 \\
\hline Real GDP & 87.0 & 63.8 & 87.3 & 15.2 & 30.3 & 10.9 \\
\hline
\end{tabular}




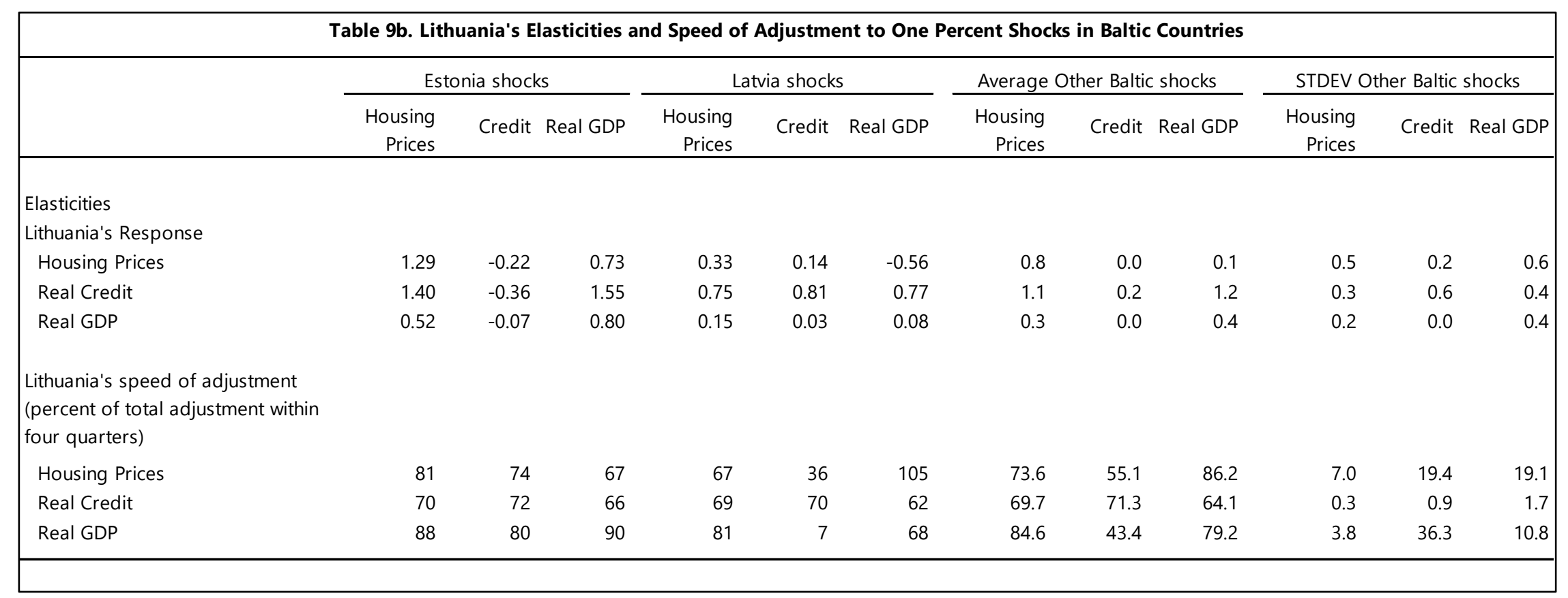




\begin{tabular}{|c|c|c|c|c|c|c|c|c|c|c|c|c|c|c|c|c|c|c|}
\hline & \multicolumn{3}{|c|}{ Denmark } & \multicolumn{3}{|c|}{ Finland shocks } & \multicolumn{3}{|c|}{ Norway shocks } & \multicolumn{3}{|c|}{ Sweden shocks } & \multicolumn{3}{|c|}{ Average Nordic shocks } & \multicolumn{3}{|c|}{ STDEV Nordic shocks } \\
\hline & $\begin{array}{r}\text { Housing } \\
\text { Prices } \\
\end{array}$ & Credit & Real GDP & $\begin{array}{r}\text { Housing } \\
\text { Prices } \\
\end{array}$ & Credit & Real GDP & $\begin{array}{r}\text { Housing } \\
\text { Prices } \\
\end{array}$ & Credit & Real GDP & $\begin{array}{r}\text { Housing } \\
\text { Prices } \\
\end{array}$ & Credit & Real GDP & $\begin{array}{r}\text { Housing } \\
\text { Prices } \\
\end{array}$ & Credit & Real GDP & $\begin{array}{r}\text { Housing } \\
\text { Prices } \\
\end{array}$ & Credit & Real GDP \\
\hline \multicolumn{19}{|c|}{ Elasticities } \\
\hline \multicolumn{19}{|c|}{ Lithuania's Response } \\
\hline Housing Prices & 2.56 & 2.80 & -1.80 & 1.30 & 0.72 & 5.40 & -0.68 & -0.75 & 0.05 & -0.85 & -0.46 & 3.90 & 0.6 & 0.6 & 1.9 & 1.4 & 1.4 & 2.9 \\
\hline Real Credit & 4.50 & 8.80 & -2.40 & 4.40 & 3.00 & 6.30 & 0.51 & -0.34 & 1.69 & 0.70 & -0.26 & 6.50 & 2.5 & 2.8 & 3.0 & 1.9 & 3.7 & 3.7 \\
\hline Real GDP & 1.03 & 0.60 & 0.37 & 0.38 & 0.19 & 2.53 & -0.28 & -0.30 & 0.36 & -0.55 & -0.15 & 2.24 & 0.1 & 0.1 & 1.4 & 0.6 & 0.3 & 1.0 \\
\hline \multicolumn{19}{|c|}{$\begin{array}{l}\text { Lithuania's speed of adjustment } \\
\text { (percent of total adjustment within } \\
\text { four quarters) }\end{array}$} \\
\hline Housing Prices & 74 & 64 & 81 & 58 & 53 & 80 & 97 & 87 & 71 & 104 & 87 & 74 & 83.3 & 72.7 & 76.4 & 18.0 & 14.7 & 4.2 \\
\hline Real Credit & 71 & 69 & 71 & 70 & 70 & 67 & 78 & 62 & 65 & 86 & 65 & 69 & 76.4 & 66.6 & 68.0 & 6.2 & 3.3 & 2.2 \\
\hline Real GDP & 83 & 55 & 105 & 61 & 53 & 90 & 107 & 95 & 83 & 102 & 94 & 87 & 88.2 & 74.0 & 91.4 & 18.2 & 20.2 & 8.4 \\
\hline
\end{tabular}


Table 10. Lithuania's Elasticities to One Percent Aggregate Shocks in Baltic and Nordic Countries 1/

\begin{tabular}{|c|c|c|c|c|c|c|}
\hline & Denmark & Estonia & Finland & Latvia & Norway & Sweden \\
\hline \multicolumn{7}{|c|}{ Lithuania's Response } \\
\hline Housing Prices & 1.2 & 0.6 & 2.5 & 0.0 & -0.5 & 0.9 \\
\hline Real Credit & 3.6 & 0.9 & 4.6 & 0.8 & 0.6 & 2.3 \\
\hline Real GDP & 0.7 & 0.4 & 1.0 & 0.1 & -0.1 & 0.5 \\
\hline
\end{tabular}

1/ Aggregate shocks refer to a combined (average) housing price, credit, and real GDP shock. 
Figure 1. Impact of a Regional Credit Shock

Accumulated Response to Cholesky One S.D. (d.f. adjusted) Innovations \pm 2 S.E.

Accumulated Response of $D\left(L N \_H P I\right)$ to $D\left(L N \_C R\right)$

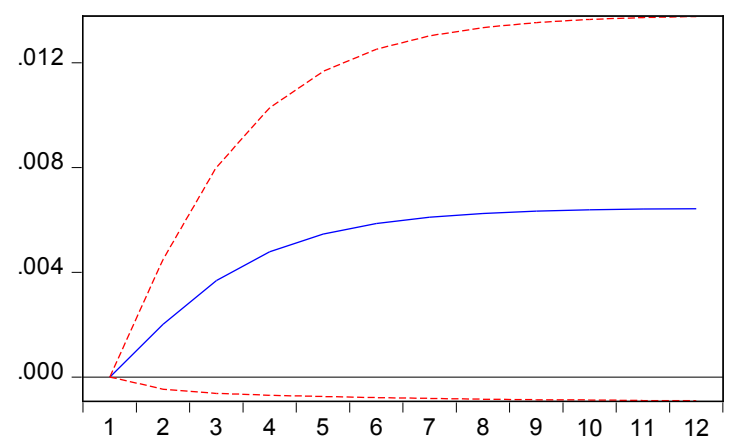

Accumulated Response of $D\left(L N \_C R\right)$ to $D\left(L N \_C R\right)$

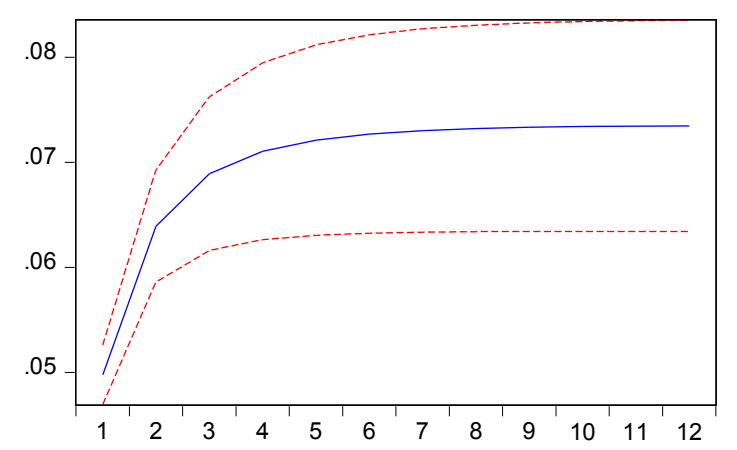

Accumulated Response of $D\left(L N \_G D P\right)$ to $D\left(L N \_C R\right)$

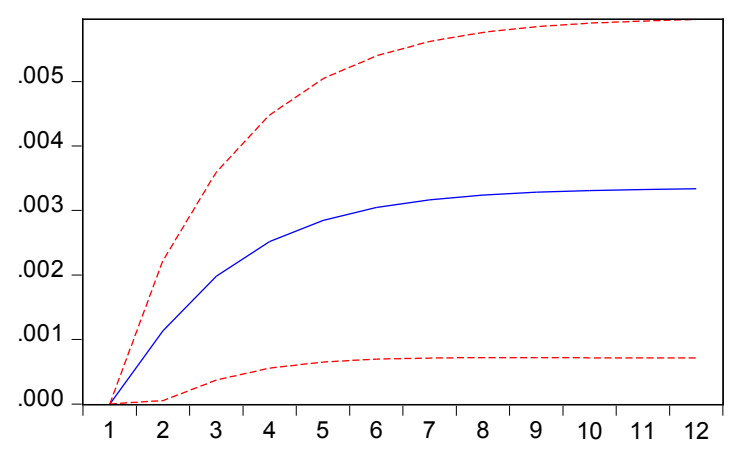


Figure 2. Impact of a Regional Housing Price Shock

Accumulated Response to Cholesky One S.D. (d.f. adjusted) Innovations \pm 2 S.E.

Accumulated Response of $D\left(L N \_H P I\right)$ to $D\left(L N \_H P I\right)$

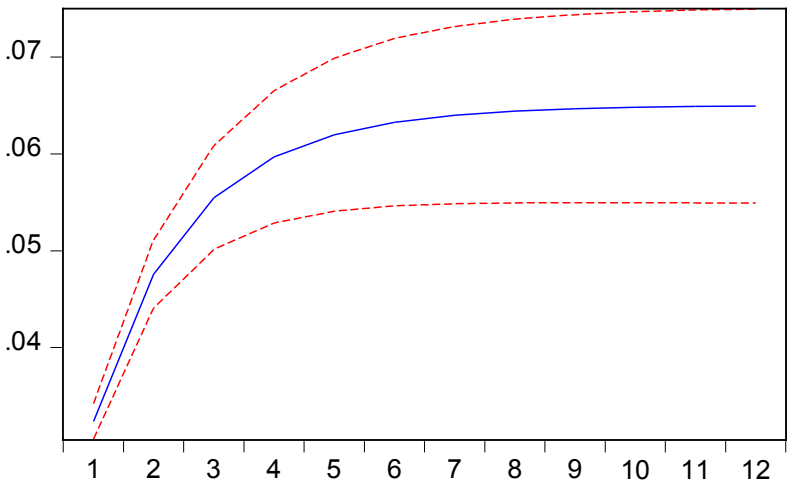

Accumulated Response of $\mathrm{D}\left(\mathrm{LN} \_\mathrm{CR}\right)$ to $\mathrm{D}\left(\mathrm{LN} \_\mathrm{HPI}\right)$

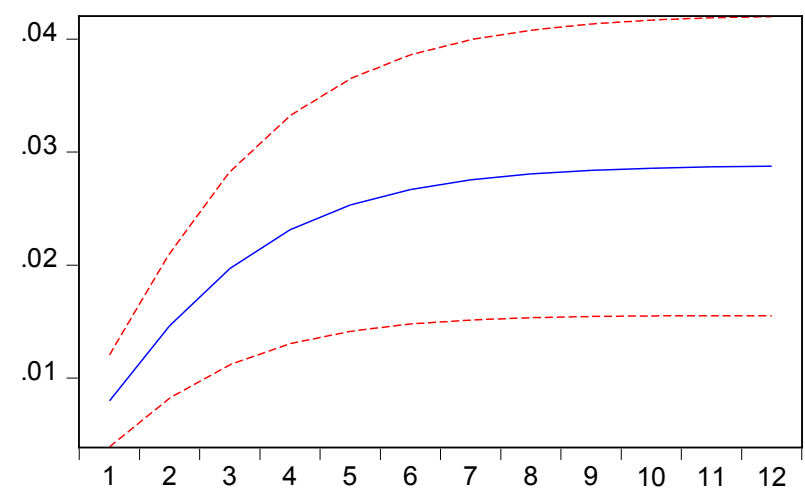

Accumulated Response of D(LN_GDP) to D(LN_HPI)

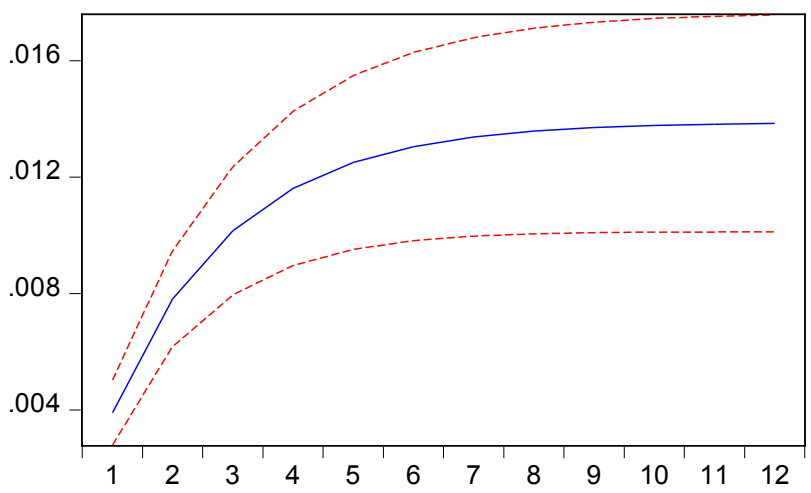


Figure 3. Impact of a Regional Real GDP Shock

Accumulated Response to Cholesky One S.D. (d.f. adjusted) Innovations \pm 2 S.E.

Accumulated Response of $D\left(L N \_H P I\right)$ to $D\left(L N \_G D P\right)$

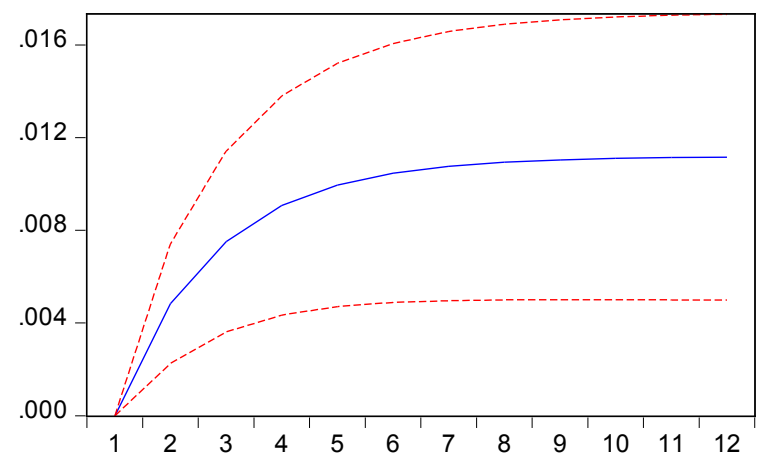

Accumulated Response of $D\left(L N \_C R\right)$ to $D\left(L N \_G D P\right)$

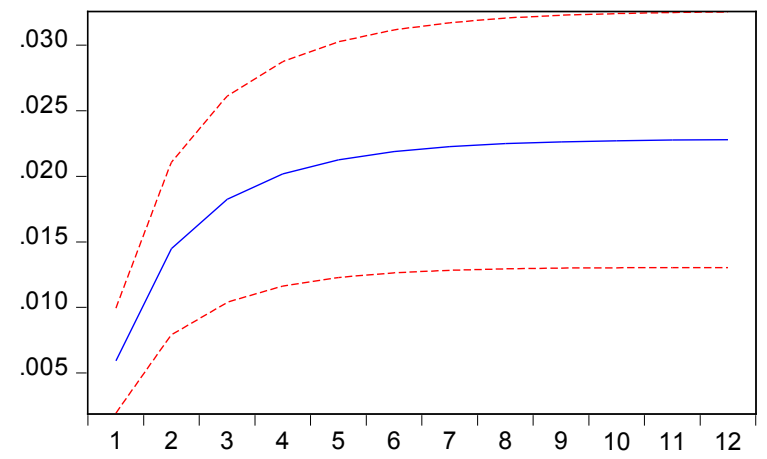

Accumulated Response of $D\left(L N \_G D P\right)$ to $D\left(L N \_G D P\right)$

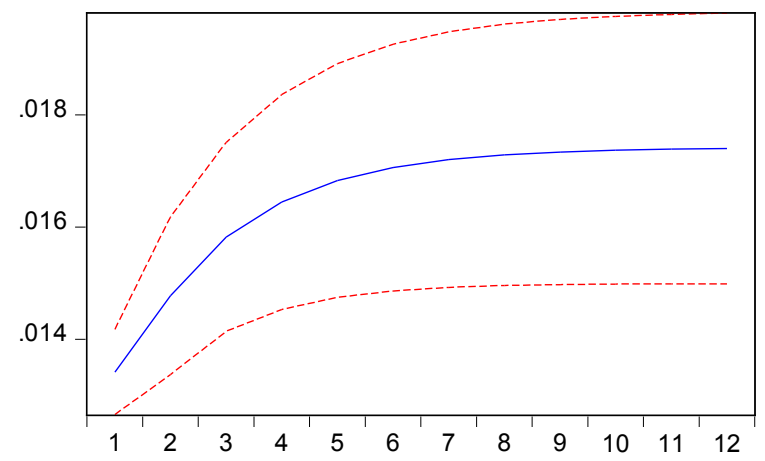


Figure 4. Impact of a Credit Shock in Lithuania
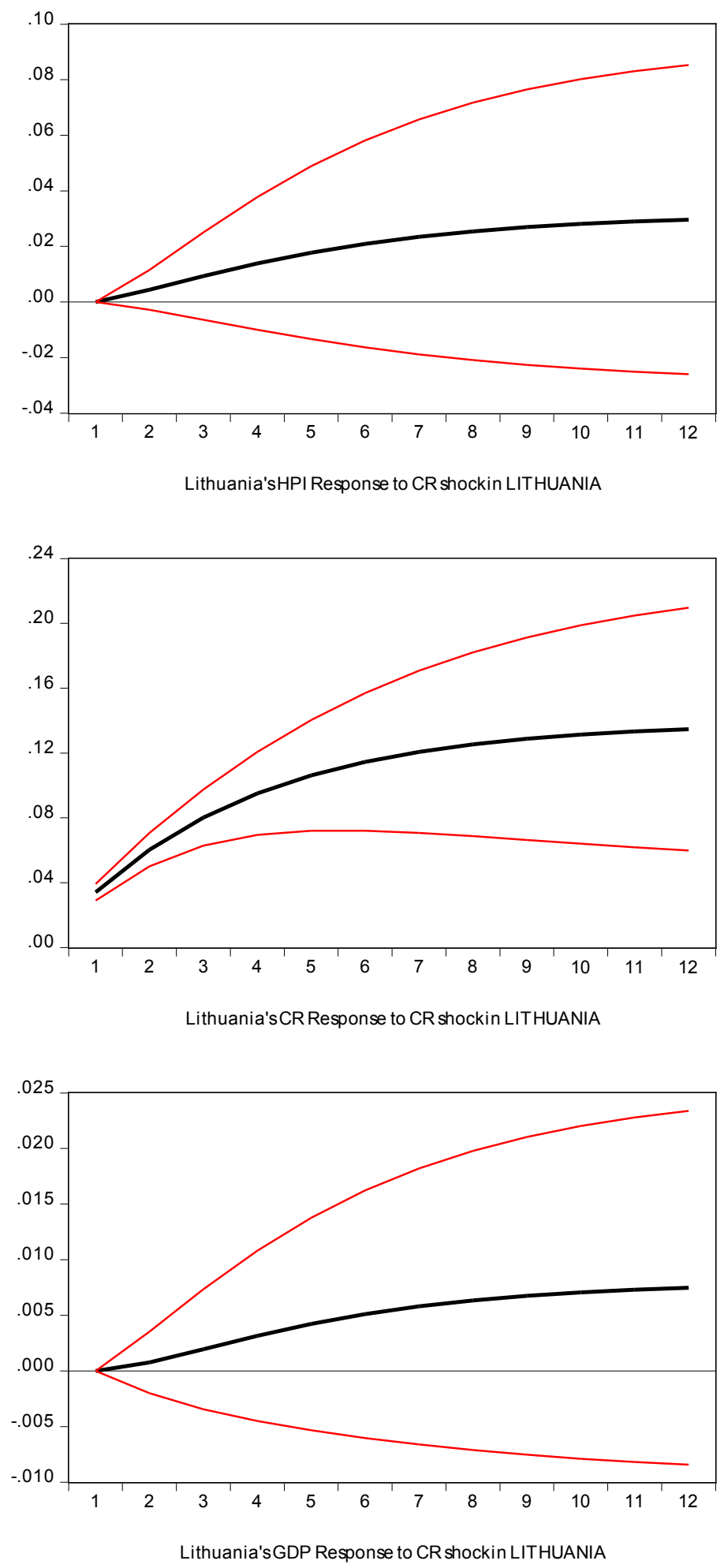
Figure 5. Impact of a Housing Price Shock in Lithuania
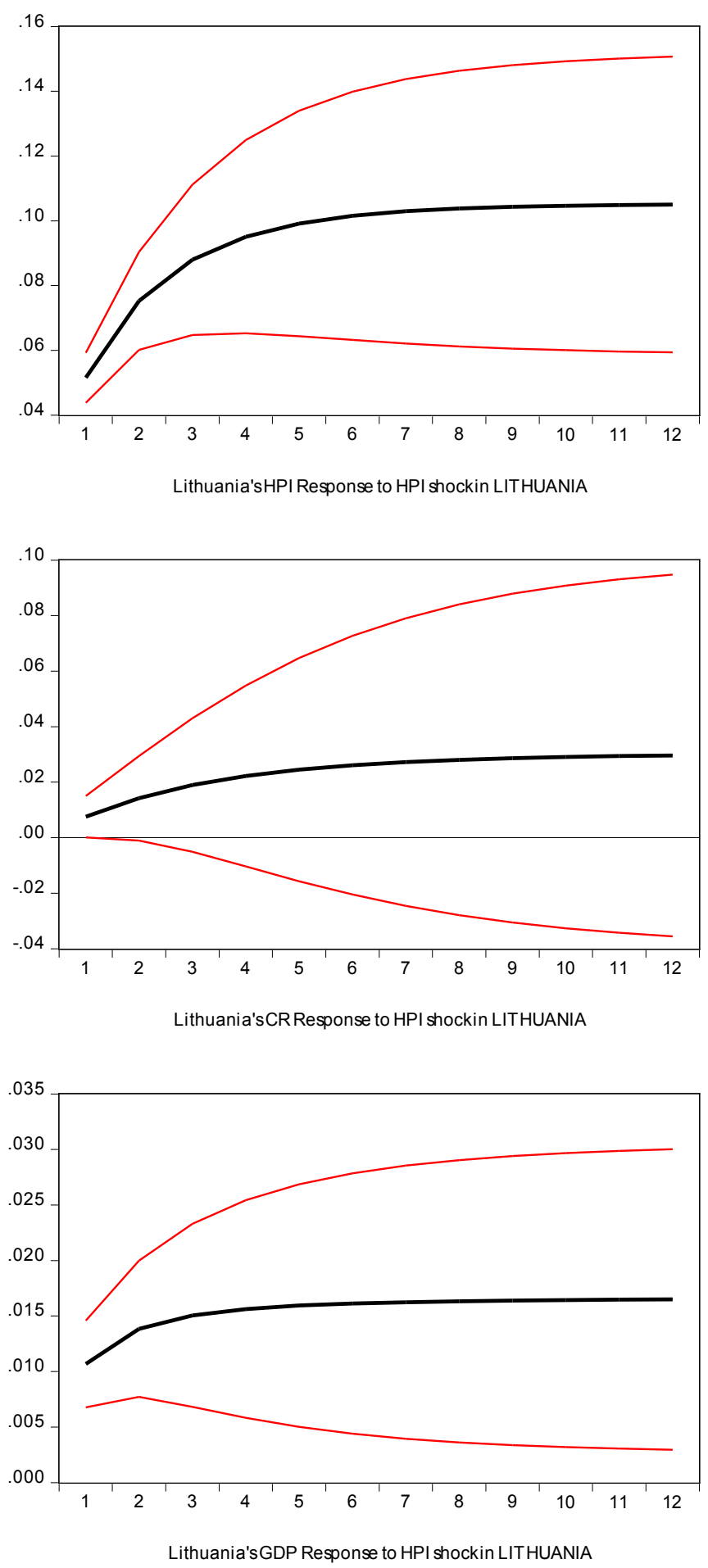
Figure 6. Impact of a Real GDP Shock in Lithuania
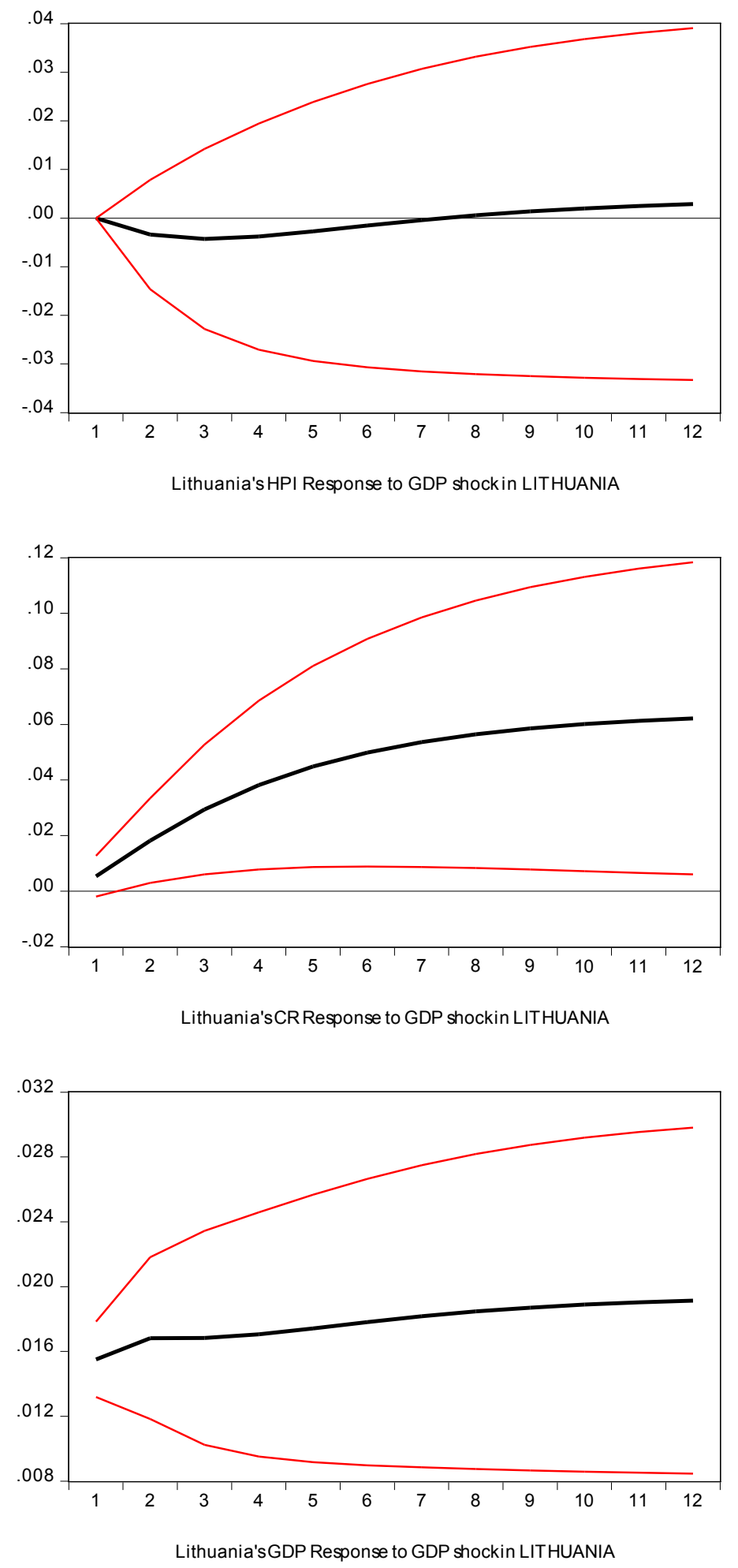

(CInternational Monetary Fund. Not for Redistribution 
Figure 7. Impact of a Country-Specific Credit Shock on Lithuania's Real Credit
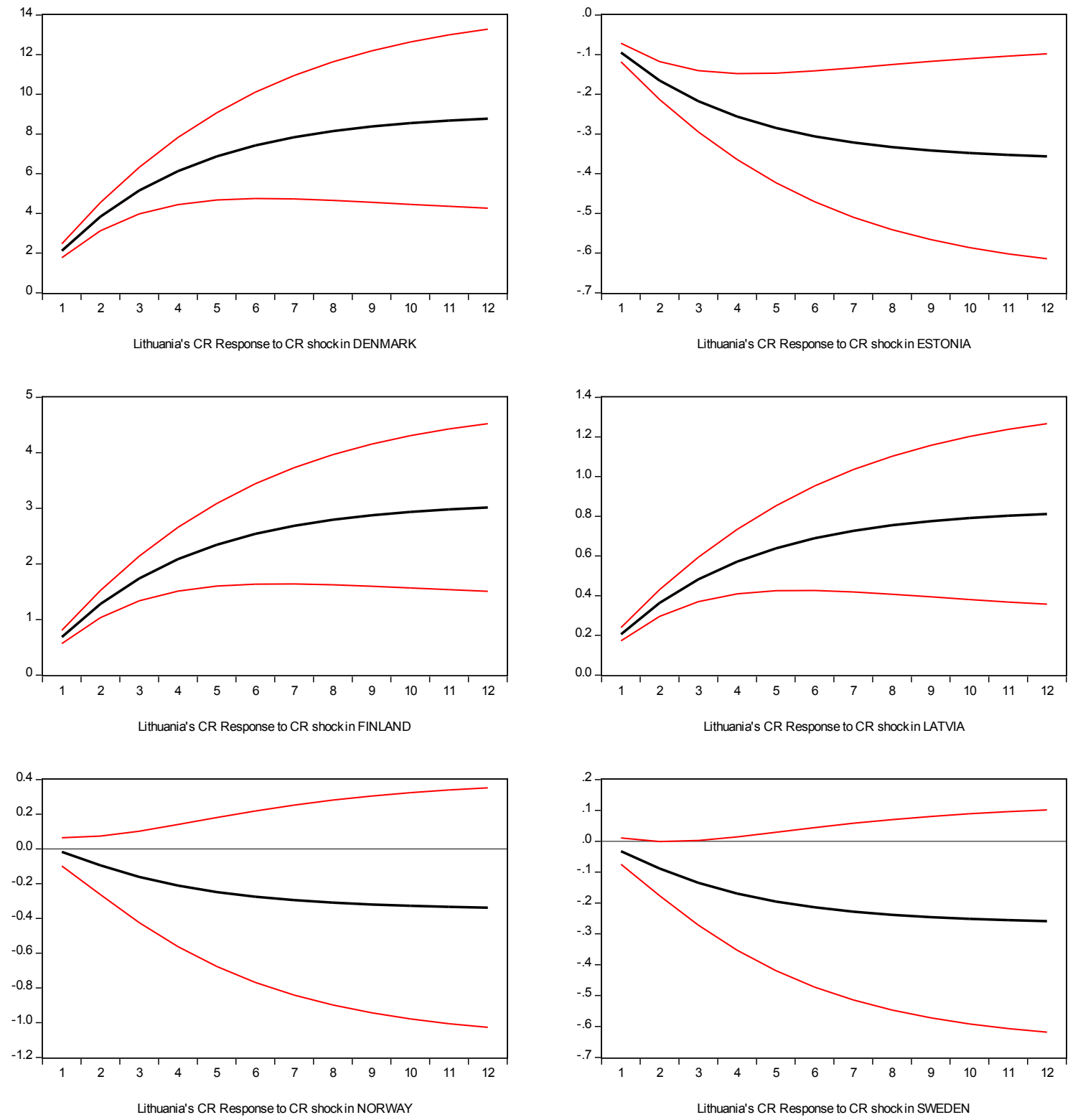
Figure 8. Impact of a Country-Specific Housing Price Shock on Lithuania's Housing Prices

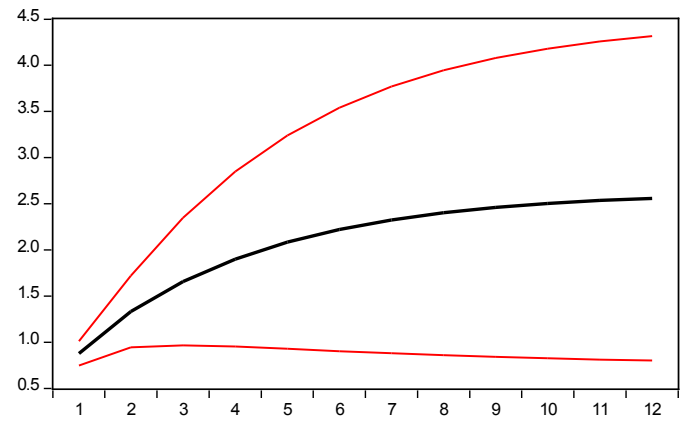

Lithuania's HPI Response to HPI shockin DENMARK

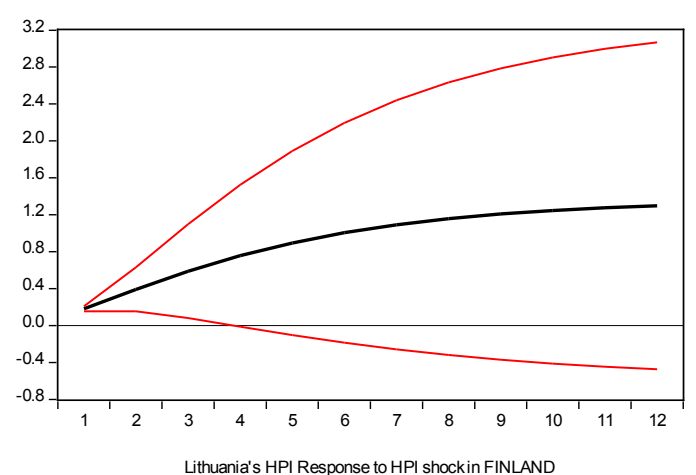

Lithuania's HPI Response to HPI shockin FINLAND

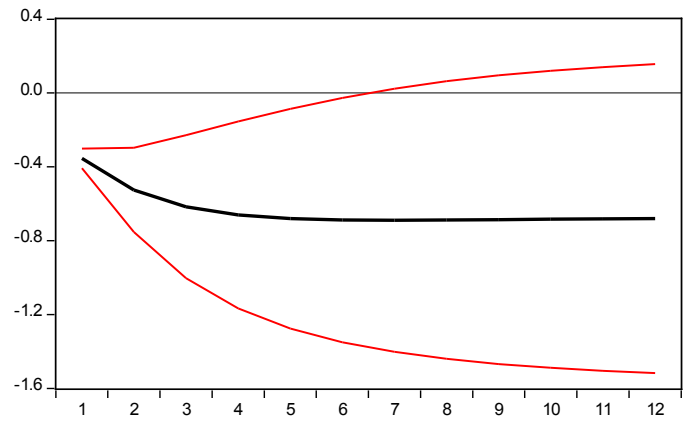

Lithuania's HPI Response to HPI shockin NORWAY

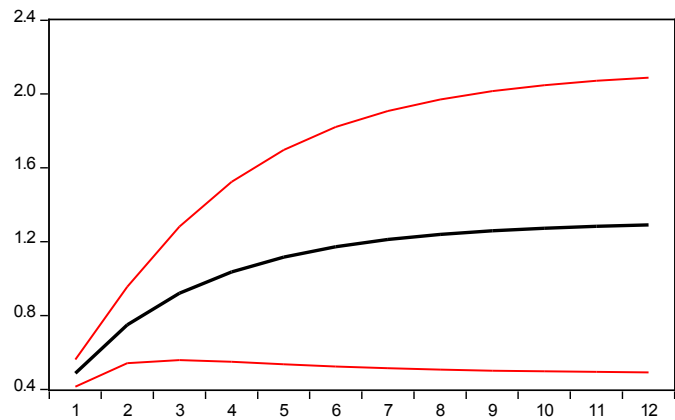

Lithuania's HPI Response to HPI shockin ESTONIA
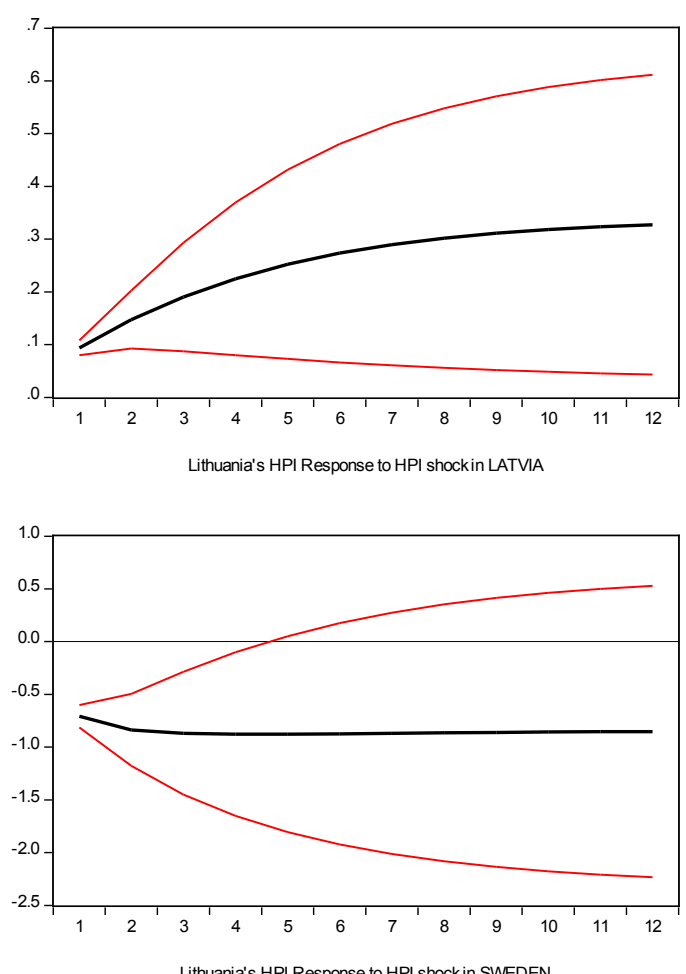

Lithuania's HPI Response to HPI shockin SWEDEN 


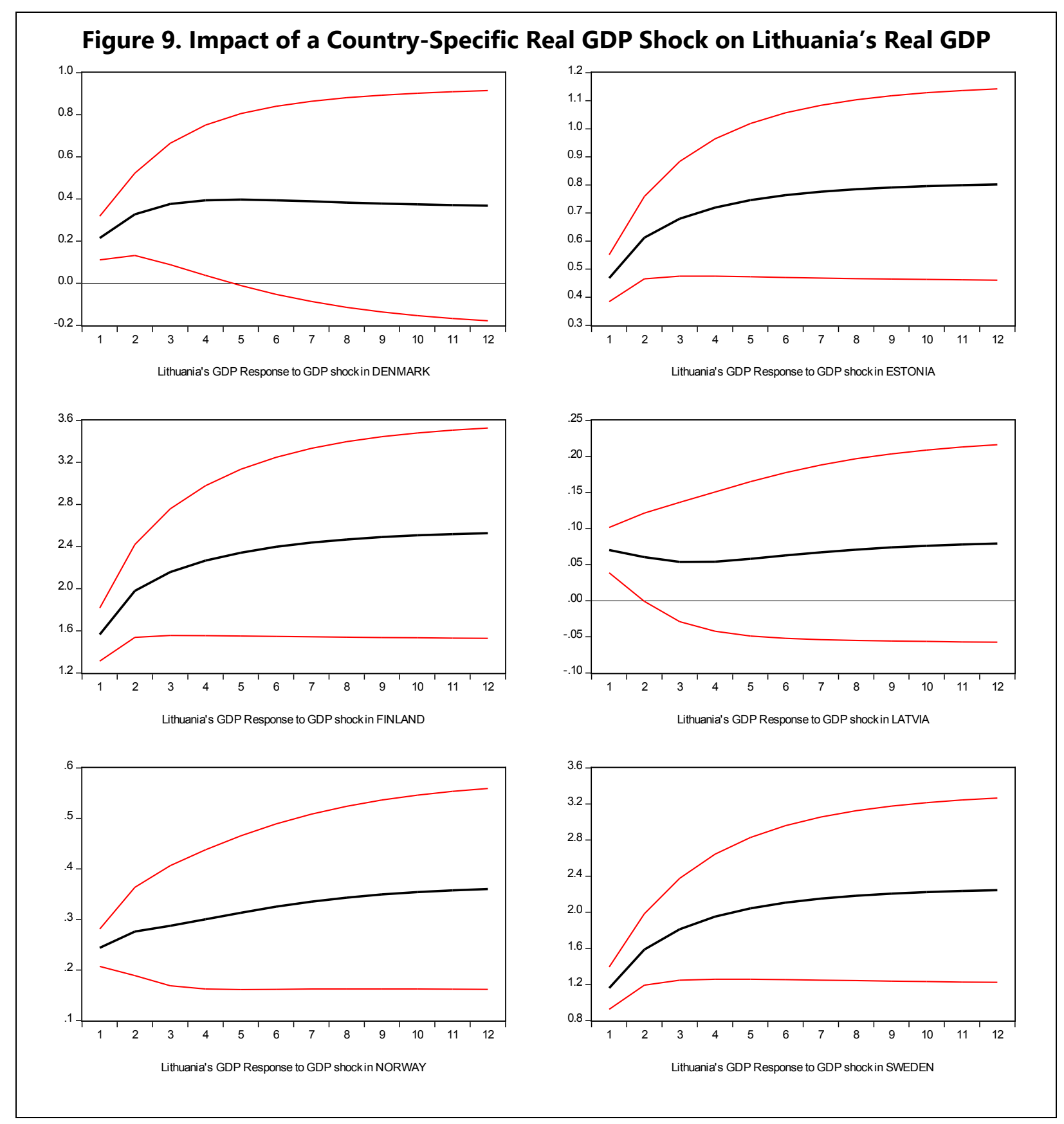

CInternational Monetary Fund. Not for Redistribution 


\section{Annex I. Data Coverage and Sources}

Sample Period: 1995Q1-2017Q3

Coverage: Denmark, Estonia, Finland, Latvia, Lithuania, Norway, Sweden

\begin{tabular}{|c|c|c|}
\hline Variable & Definition & Source \\
\hline Real GDP & $\begin{array}{l}\text { Chained volume series, } \\
\text { seasonally and working day } \\
\text { adjusted in millions of euros. }\end{array}$ & Haver. \\
\hline Credit & $\begin{array}{l}\text { Nominal credit to household } \\
\text { and nonfinancial corporate } \\
\text { sectors, seasonally adjusted, } \\
\text { converted to euros, and } \\
\text { deflated using the HICP (or } \\
\text { national CPI if not available). }\end{array}$ & $\begin{array}{l}\text { Haver, National statistical } \\
\text { offices, IFS, Eurostat, and staff } \\
\text { estimates. }\end{array}$ \\
\hline Housing prices & $\begin{array}{l}\text { Real house price index, } \\
\text { seasonally adjusted. If not } \\
\text { available, proxied by rent } \\
\text { prices, seasonally adjusted. }\end{array}$ & OECD and staff estimates. \\
\hline Interest rate & $\begin{array}{l}\text { 3-month money market } \\
\text { interest rate }\end{array}$ & $\begin{array}{l}\text { Eurostat, IFS, and national } \\
\text { authorities. }\end{array}$ \\
\hline Consumer inflation & $\begin{array}{l}\text { Harmonized consumer price } \\
\text { index }\end{array}$ & Haver. \\
\hline Deposits & $\begin{array}{l}\text { Household and NFC deposits } \\
\text { at credit institutions. }\end{array}$ & $\begin{array}{l}\text { National authorities and staff } \\
\text { estimates including } \\
\text { annualized quarterly growth } \\
\text { rates. }\end{array}$ \\
\hline Private sector indebtedness & $\begin{array}{l}\text { Liabilities (loans, securities } \\
\text { other than shares) held by } \\
\text { non-financial corporations } \\
\text { and households. }\end{array}$ & $\begin{array}{l}\text { Eurostat and staff estimates, } \\
\text { including annualized } \\
\text { quarterly growth rates. }\end{array}$ \\
\hline Capital Adequacy Ratio & $\begin{array}{l}\text { Regulatory capital as } \\
\text { a percent of risk-weighted } \\
\text { assets. }\end{array}$ & $\begin{array}{l}\text { FSI database, World Bank } \\
\text { Global Financial Development } \\
\text { Database and staff estimates } \\
\text { including annualized } \\
\text { quarterly growth rates. }\end{array}$ \\
\hline
\end{tabular}




\begin{tabular}{|l|l|l|}
\hline Return on assets & $\begin{array}{l}\text { Return on assists for } \\
\text { depository institutions. }\end{array}$ & $\begin{array}{l}\text { FSI database, World Bank } \\
\text { Global Financial Development } \\
\text { Database and staff estimates, } \\
\text { including annualized } \\
\text { quarterly growth rates. }\end{array}$ \\
\hline EMBI & $\begin{array}{l}\text { J.P. Morgan EMBI Global Total } \\
\text { Return Index }\end{array}$ & Bloomberg. \\
\hline World growth & $\begin{array}{l}\text { GDP of OECD countries, } \\
\text { volume estimates, seasonally } \\
\text { adjusted. }\end{array}$ & OECD database. \\
\hline Productivity growth & $\begin{array}{l}\text { Real labor productivity per } \\
\text { hour worked (NSA, } \\
2010=100), \text { seasonally } \\
\text { Adjusted. }\end{array}$ & Haver and staff estimates. \\
\hline
\end{tabular}


Annex II: Underlying Data on Credit, Housing Prices, and Real GDP

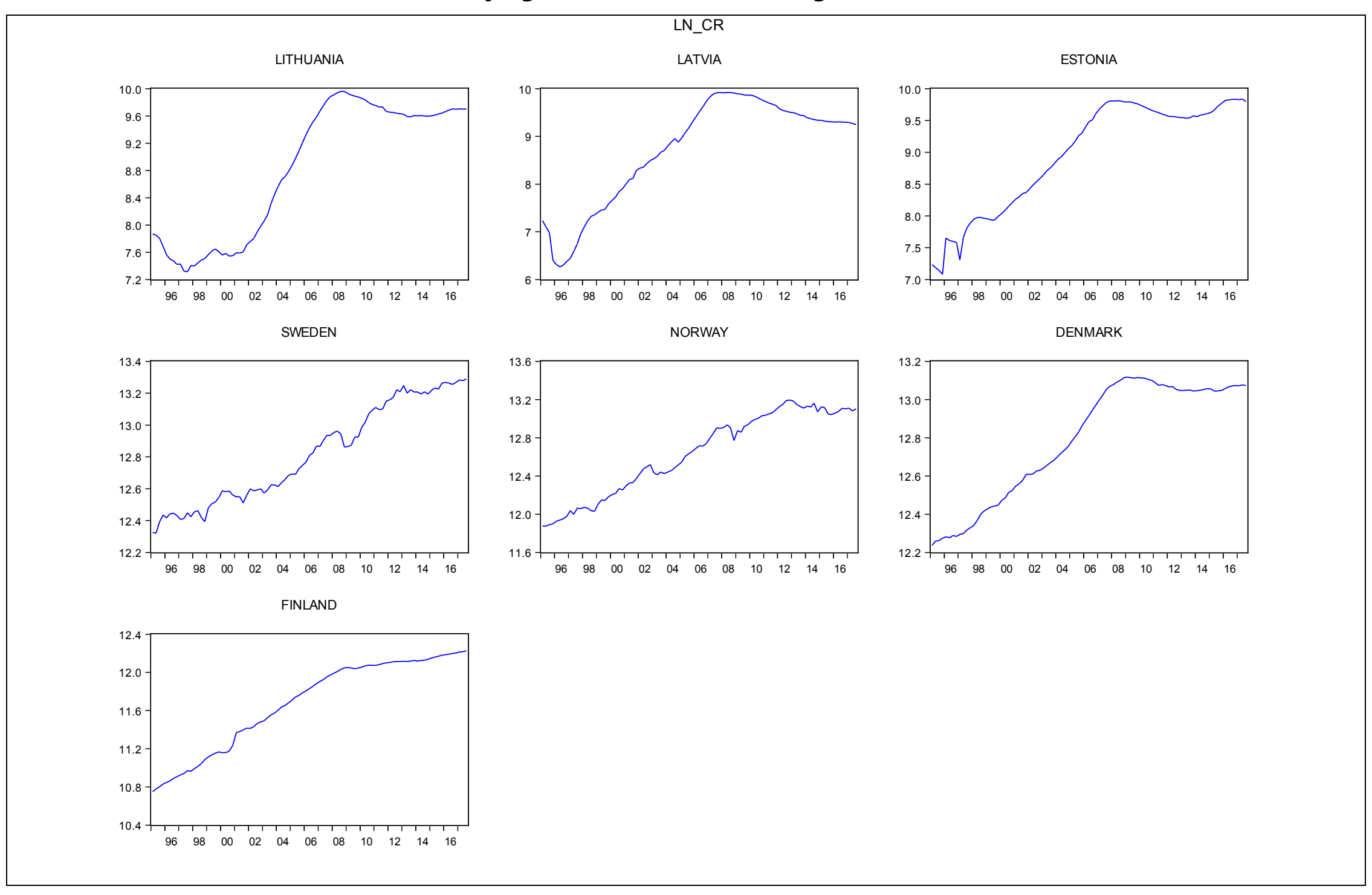




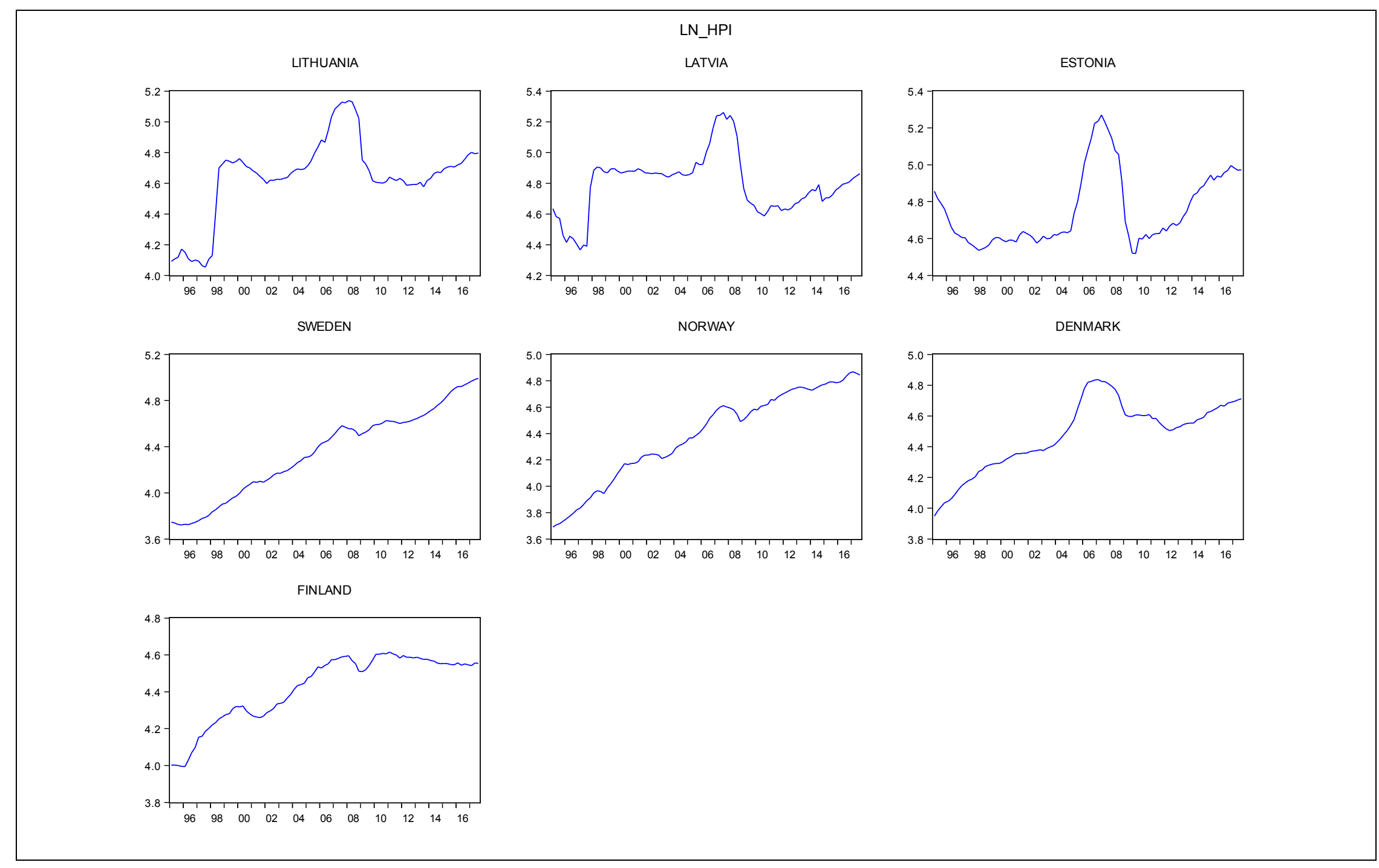




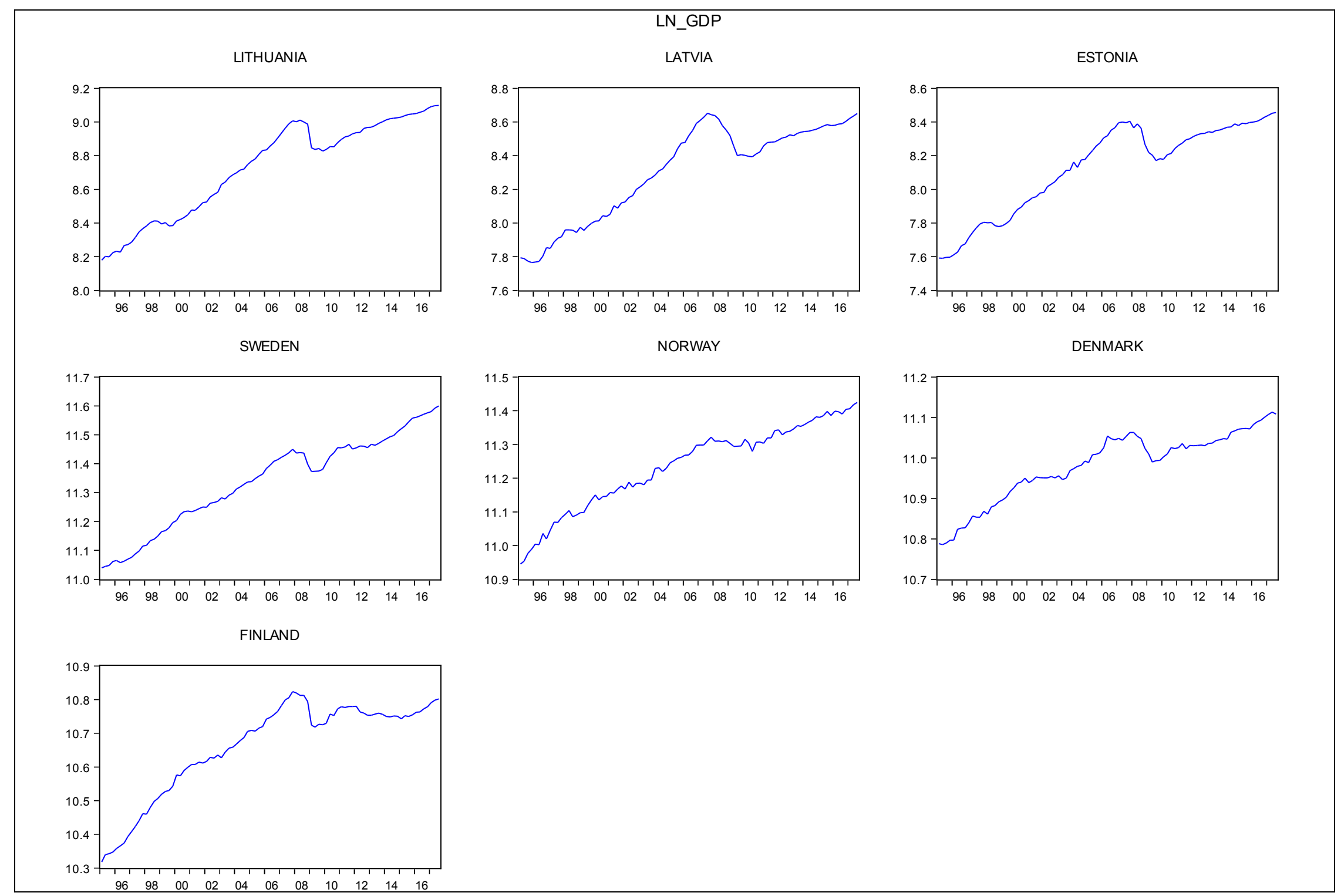


Annex III. Impact of Cross-Country Shocks on Lithuania

Figure A1. Lithuania's Credit Response to a Housing Price Shock in Other Countries
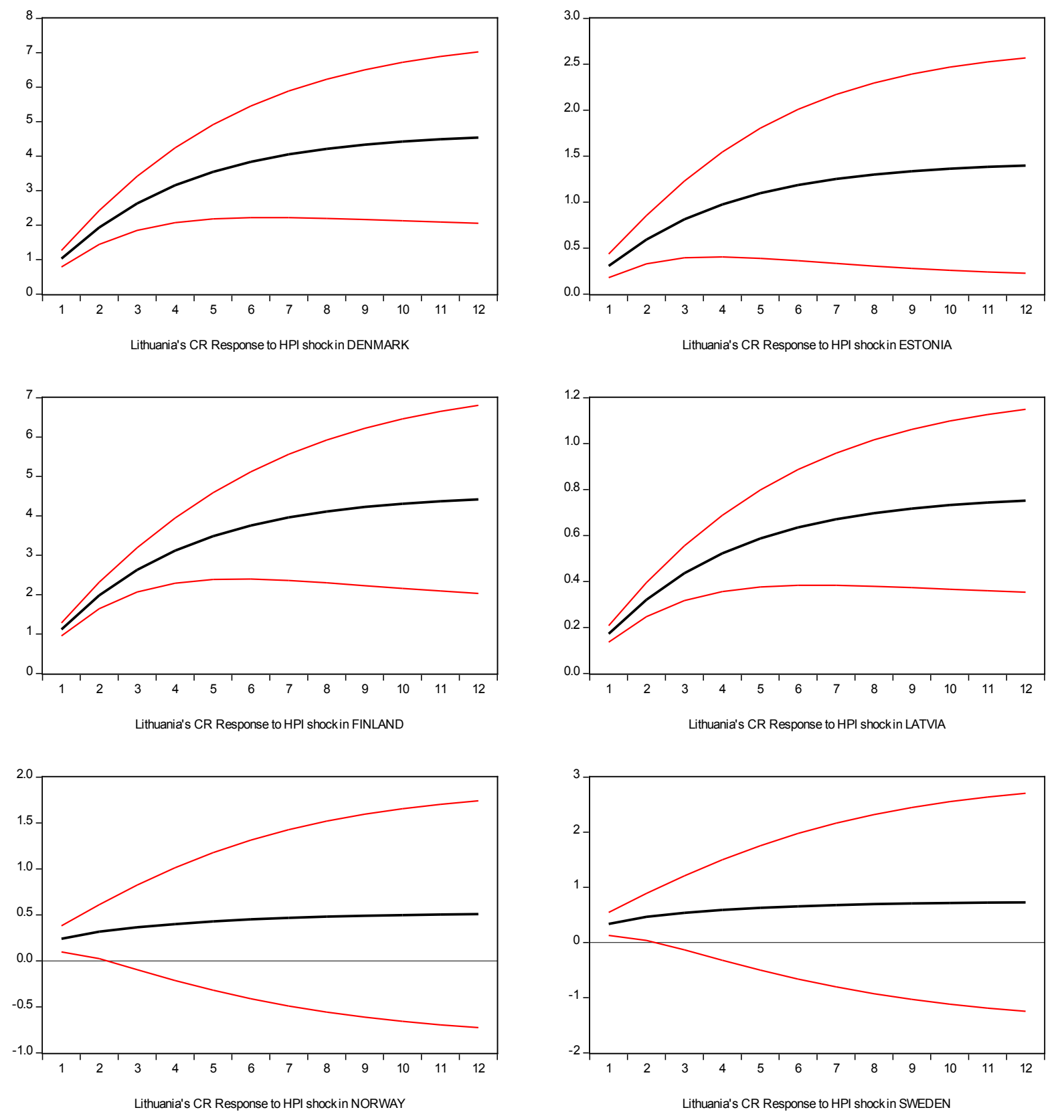
Figure A2. Lithuania's Real GDP Response to a Housing Price Shock in Other Countries
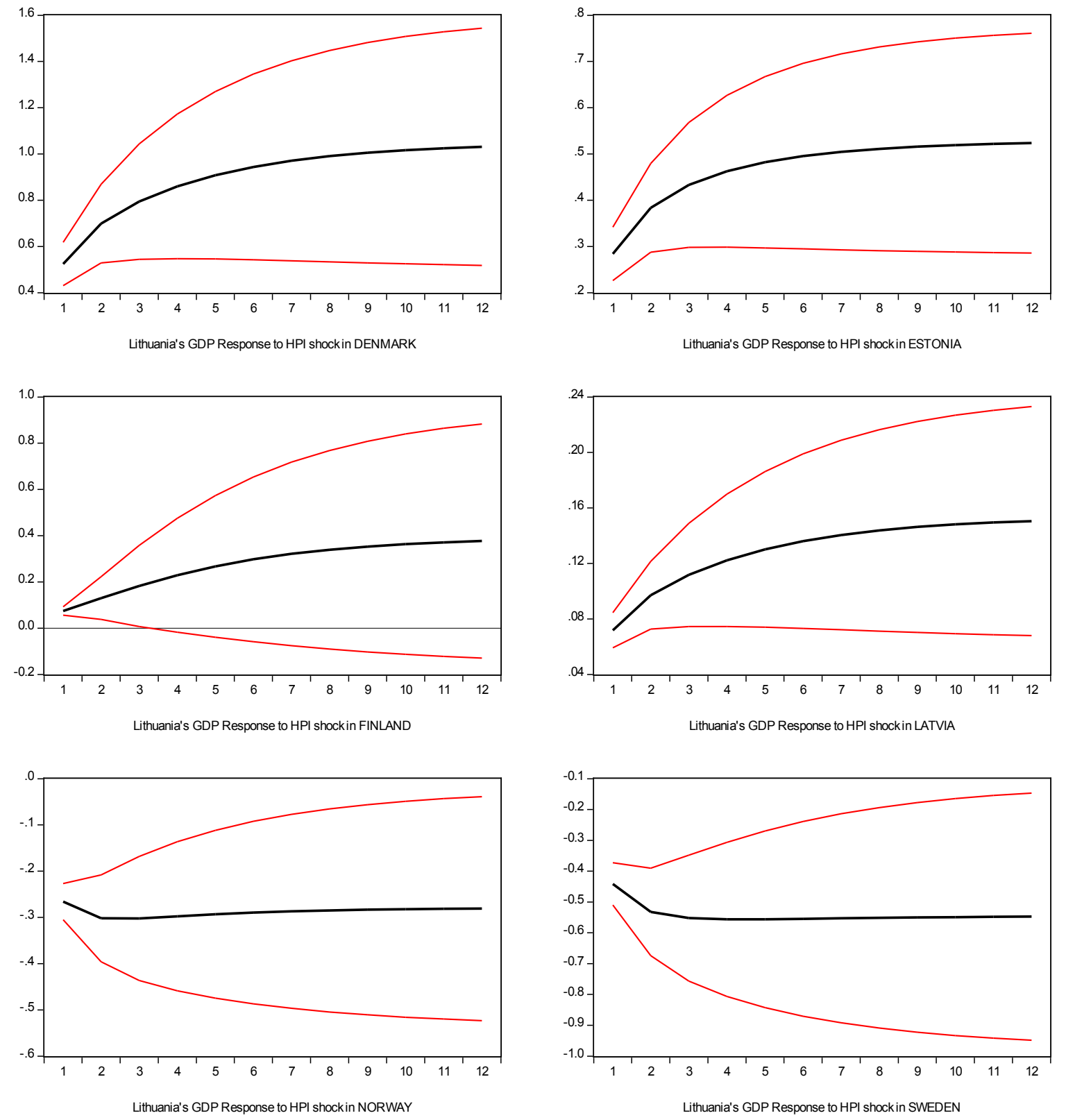
Figure A3. Lithuania's Housing Price Response to a Credit Shock in Other Countries
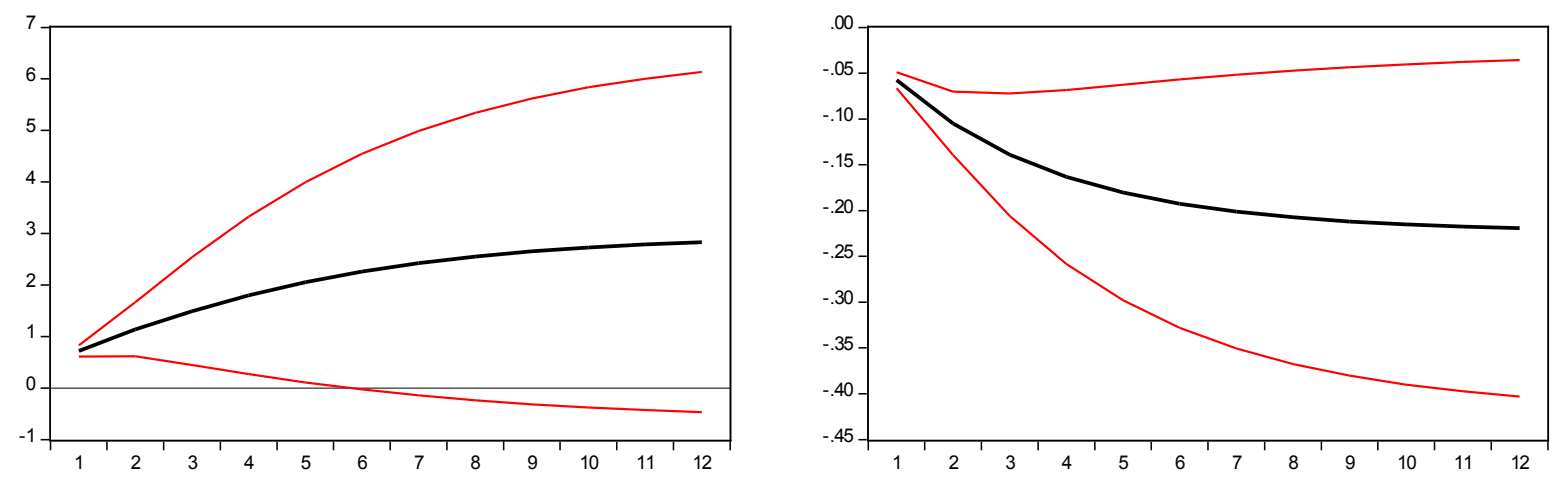

Lithuania's HPI Response to CR shockin DENMARK

Lithuania's HPI Response to CR shockin ESTONIA

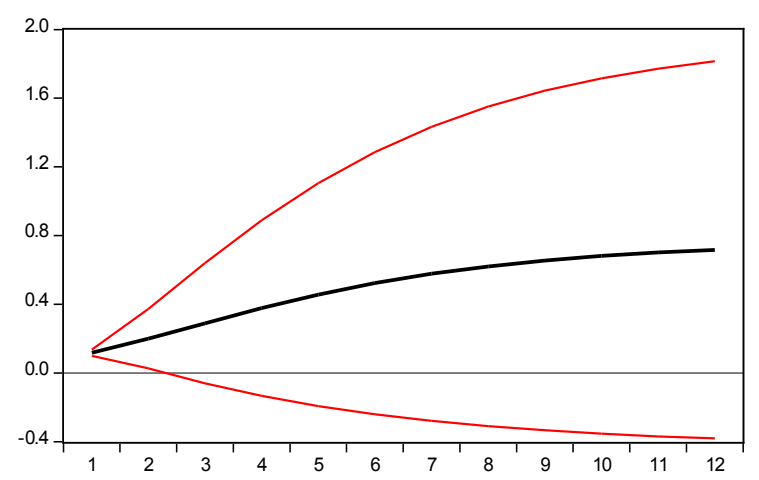

Lithuania's HPI Response to CR shockin FINLAND
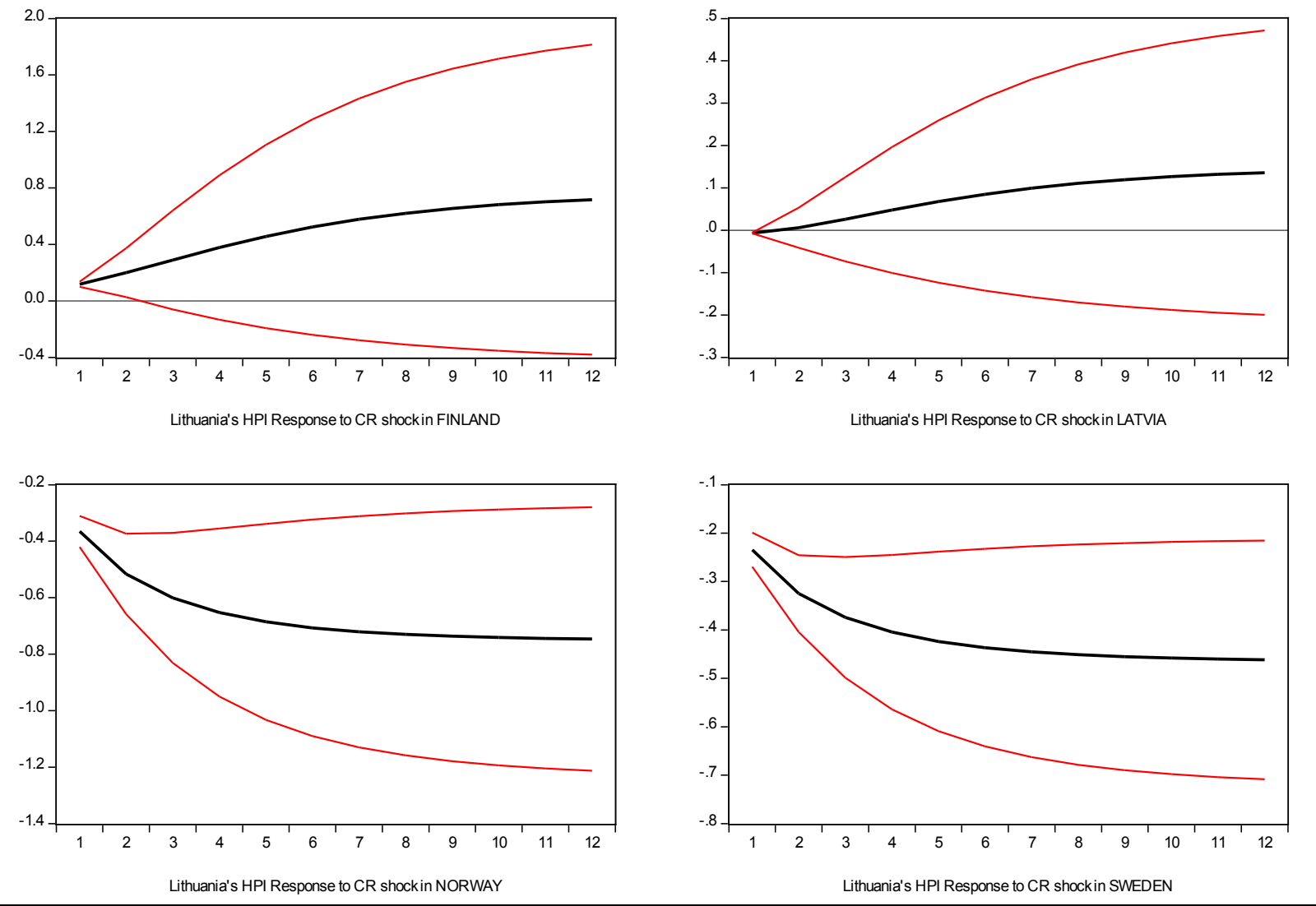


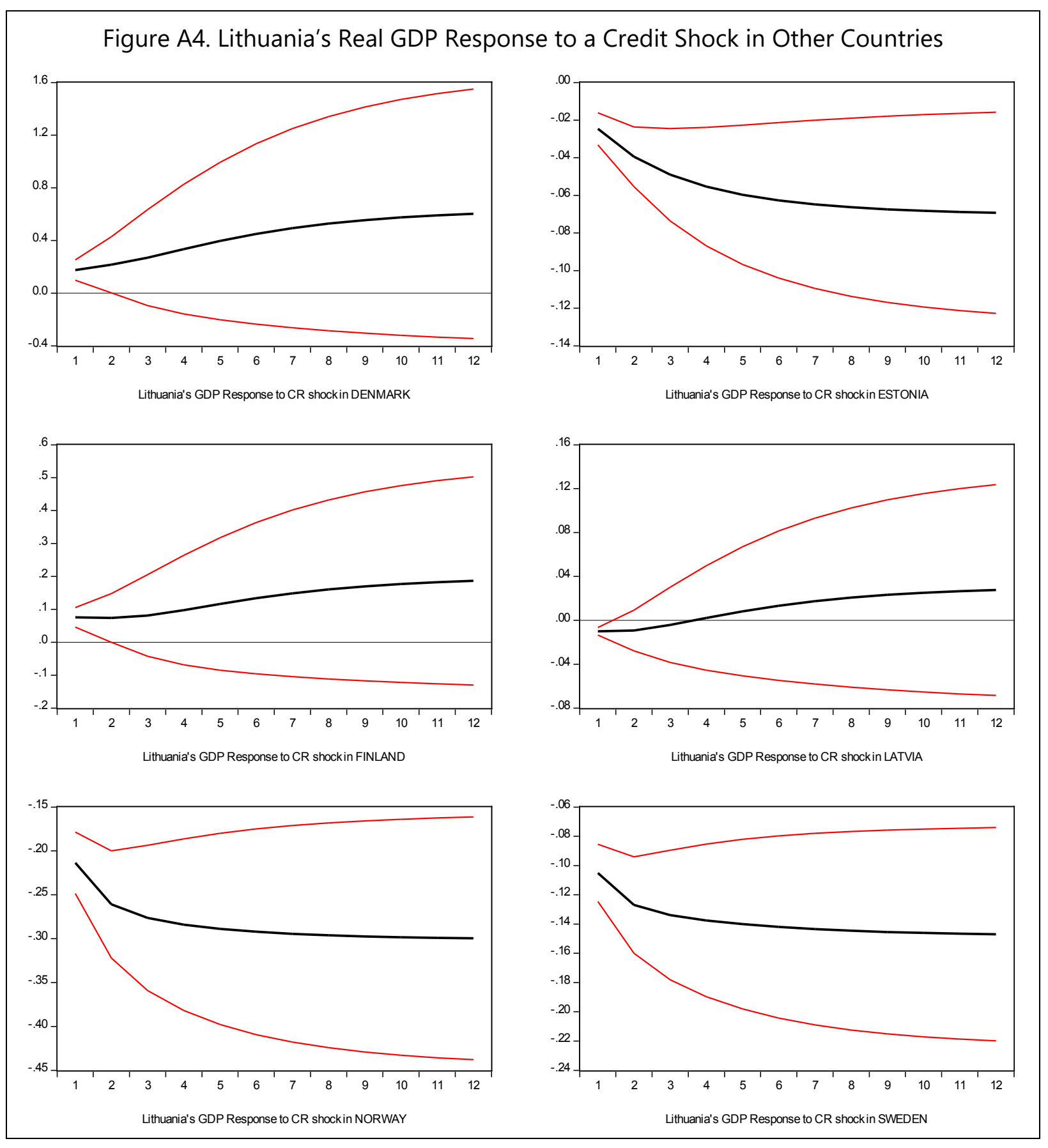


Figure A5. Lithuania's Housing Price Response to a Real GDP Shock in Other Countries
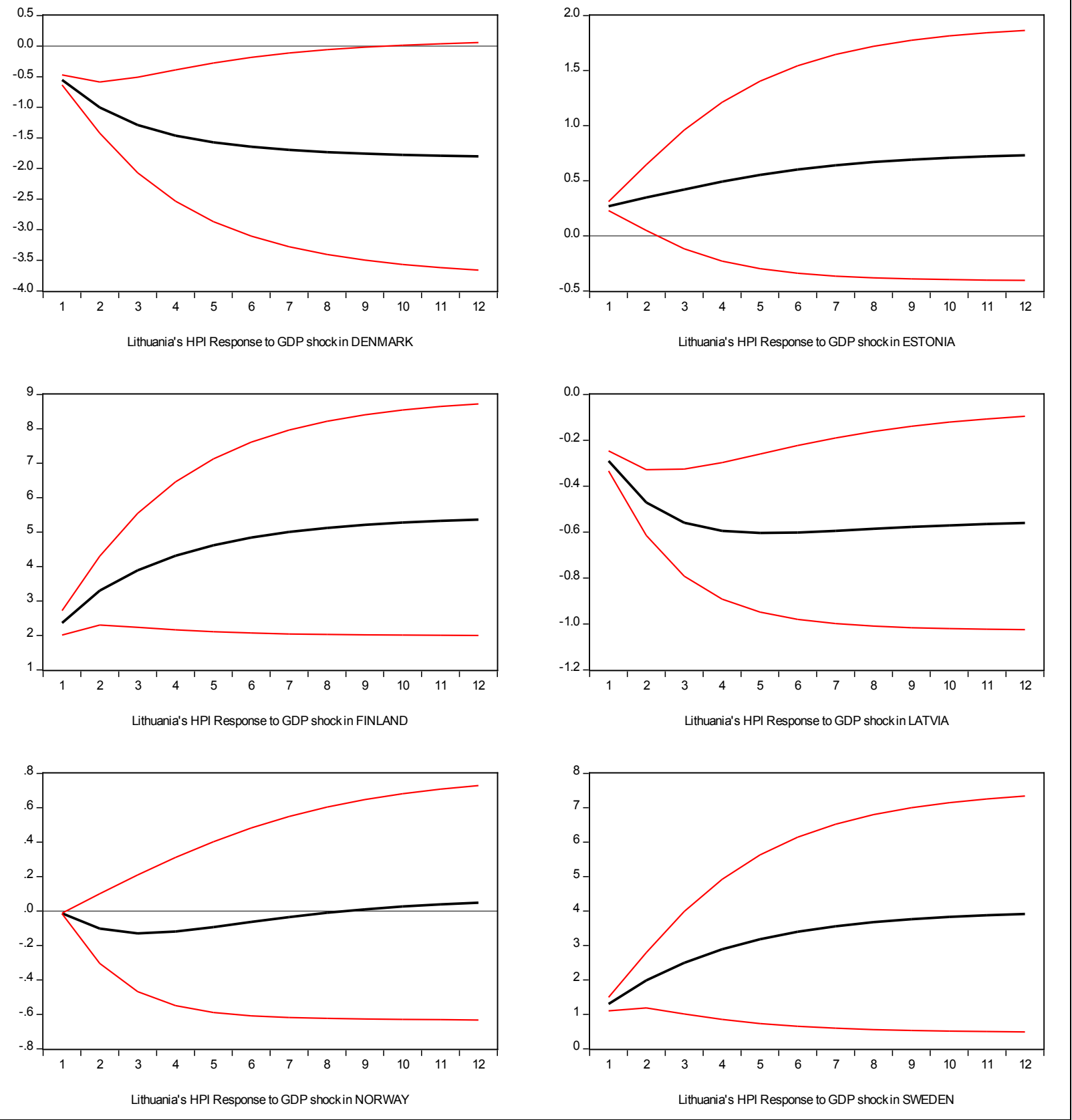


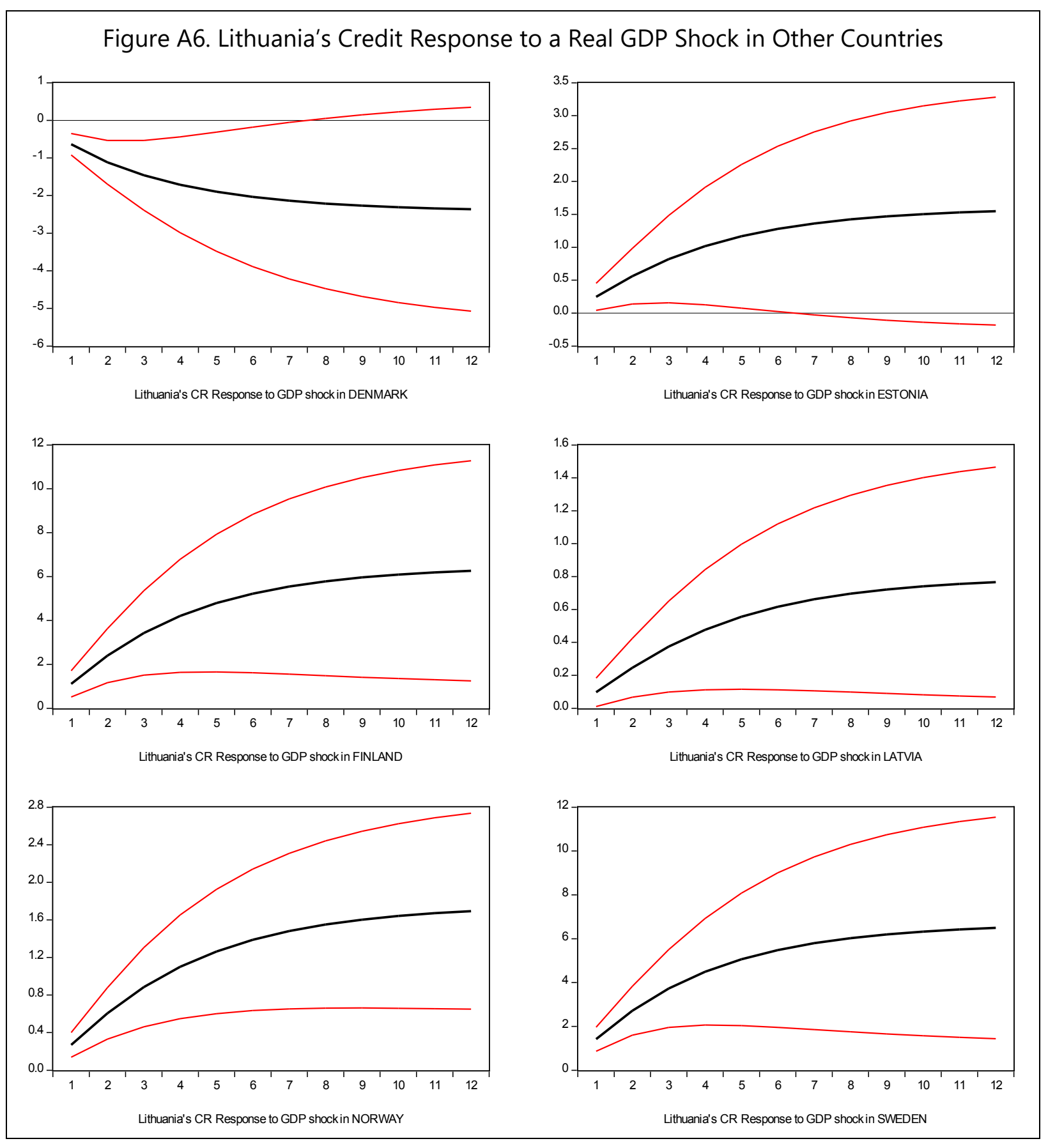

